\title{
COMMENT
}

\section{TERM PAPER COMPANIES AND THE CONSTITUTION*}

"Law can discover sin, but not remove." Milton, Paradise Lost, Book XII, line 290.

As commercial term paper companies ${ }^{1}$ have emerged as ex-

* The Duke LAw JourNal gratefully acknowledges the assistance of the Institute of Government of the University of North Carolina in the preparation of the research for this Comment. The background correspondence and all court papers cited are on file at the Institute, located in Chapel Hill, North Carolina.

1. Term paper companies offer to prospective student purchasers two varieties of papers-original papers and "copy" papers. "Copy" papers are either re-typed or duplicated from completed term papers already in a conipany's files. The papers in such files may be acquired in several ways. Companies typically insert into their permanent files a copy of each original paper prepared, so that it becomes the master for "copy" papers taken from it in the future: "When a student special-orders a paper, we assign it to one of our writers. When it's finished one copy goes to the custonier and one goes into the file for resale." Rosenberg, Why Johnny Can't Flunk, EsQuRE, April 1973, 134, 135. Conipanies also purchase term papers from students who liave written the papers themselves and submitted thein successfully for credit in a course at an educational institution. Exhibit 10, Complaint of State of Wisconsm at 11, Bruce Inksetter, No. 997 (Wis. Dep't of Agriculture, May 16, 1972). Companies may acquire a portion of their papers by theft, perhaps by purchasing the papers from an intermediary who has himself stolen the papers. A number of papers stolen at Harvard were located in the files of a Manhattan term paper company; papers not yet located are known to have been stolen from Columbia, Cornell, the University of Massachusetts, New York University, and Syracuse University. See Chromicle of Higher Education, Feb. 22, 1972, at 5, col. 5; TrME, Mar. 27, 1972, at 76; Ambash, Trapping Term Paper Cheaters by Statute, 59 A.B.A.J. 162 (1973). Conipanies also sell or trade papers among themselves: "[The] writers submitted to defendants an original typed copy of the work plus two carbon copies .... . [The] defendants turn over the original copy to the student purchasers thereof and apparently sell or otherwise transfer the carbon copies to a Boston Company, Ward Warren Manuscripts." Affidavit of Stephen Mindell at 4, State v. Saksniit, 69 Misc. 2d 554, 332 N.Y.S.2d 343 (Sup. Ct. 1972). When a company such as Termpapers Unlimited operates on a national scale with established quasi-franchise operations, the individual term paper "franchisees" usually have complete access to the large master file of papers in the nuain offices and channel their orders for original papers througl Termpapers Unlimited rather than themselves hiring writers to prepare such papers. Statement of respondent Bruce Inksetter in Deposition of Eileen Rezak at 12, Bruce Inksetter, No. 997 (Wis. Dep't of Agriculture, May 16, 1972). The operator of a Wisconsin term paper company called sucli "copy" papers "prepackaged" rather than "copy" papers. Statenient of respondent Bruce Inksetter, in Deposition of James McFarlane Davis at 23, Bruce Ink- 
tremely profitable economic enterprises, ${ }^{2}$ plagiarism by students, previously a localized academic virus ostensibly controlled by honor codes, has become a national plague. ${ }^{3}$ Although the popular press has covered the operations of term paper companies with predictable fascination, ${ }^{4}$ the disease has yet to be subjected to a satisfactory antidote. $^{5}$ In their efforts to provide such an antidote, state legislatures

setter, No. 997 (Wis. Dep't of Agriculture, May 16, 1972). They have also been called simply "used" papers. Cheating, Inc., NewsweEx, Mar. 20, 1972, at 91.

HEREINAFTER THE FOLLOWING CITATIONS WILL BE USED IN THIS COMMENT:

Rosenberg, Why Johnny Can't Flunk, EsQUIRE, April 1973, 134 [hereinafter cited as Rosenberg];

Steinway \& Karle, Term papers for sale: Or, "What are we here for?" MrcH. ST. UNIV. ALUMNI Ass'N MAGAzINE, Jan. 1973, 8 [hereinafter cited as Steinway \& Karle]; Inc.].

Cheating, Inc., NewsweEx, Mar. 20, 1972, at 91 [hereinafter cited as Cheating

2. See note 23 infra.

3. There are suggestions that cheating in colleges and universities is not a matter of concern to attorneys general, legislatures, or judges so long as it is neither rampant nor visible. See note 17 infra. The comment of a dissenting judge in State v. Abortion Information Agency, Inc., 37 App. Div. 2d 142, 330 N.Y.S.2d 927 (1971), a case relied upon in State v. Saksnït, 69 Misc. 2d 554, 332 N.Y.S.2d 343 (Sup. Ct. 1972), the New York term paper case, is pertinent:

The volume appalled the public mind, and any service or facility which made the practice more available became an obvious target. When the service reached sizeable proportions the reactions became hysterical . . . 3 37 App. Div. 2d at 147, 330 N.Y.S.2d at 931.

Academic plagiarisin has traditionally been looked upon by legislators as of insufficient moment to deserve notice; it was formerly an internal malady of educational institutions calling for disciplinary actions of varying degrees of severity, ranging from the obligation to repeat plagiarized work to suspension or expulsion of the erring student. So long as plagiarisin was typically and essentially a solo performance, its occurrence was infrequent enough, and the penalties for infractions severe enough, for educational institutions to hold themselves out as satisfactorily self-policing. Also, so long as enrollments were small enough and teaching loads were low enough for the relationship between teacher and student to be informal rather than distant and impersonal, the cahber of a student's work could be gauged with sufficient accuracy so that the tooexcellent paper would arouse justifiable suspicious. An occasional student may have copied the paper of a "friend" or parroted a scholarly article without attribution of his ideas to their true immediate source, but plagiarism was most likely confined.

4. In addition to editorials in the New York Times, Feb. 16, 1972, at 38, col. 2, and Wall Street Journal, Apr. 26, 1972, at 16, col. 1, one television network, CBS, "did a special television report on Termpapers Unlimited." Chromicle of Higher Education, Jan. 31, 1972, at 9, col. 1 .

5. "[N]o universal, well-co-ordinated remedy has yet emerged for this situation .... Indeed, although the problem of blatant cheating may seeln clear enough, atteinpts to deal with it generate a confusing mixture of difficulties that in some instances may outweigh the original evil." Ambash, supra note 1, at 162. The Supreme Court's statement in Sweezy v. New Hampshire, 354 U.S. 234 (1957), seens in retrospect ironic: "Scholarship cannot flourish in an atmosphere of suspicion and distrust. Teachers and students inust always remain free to inquire, to study, and to evaluate .... Id. at 250. And despite the Court's statement in Shelton v. Tucker, 364 U.S. 
have responded with legislation intended to curtail the activities of term paper companies. ${ }^{6}$ In addition, disapproving judges before whom term paper cases have been brought have been asked to tailor common law tort and contract principles to the allegedly immoral conduct of defendant companies. ${ }^{\top}$

This legislative and judicial reaction may be blunted by the application of the first amendment to protect the production and sale of term papers. ${ }^{8}$ Should the first amendment apply, governmental responses that enjoin or prohibit the sale rather than use of terin papers would appear to constitute traditionally suspect prior restraints on protected activity. ${ }^{9}$ In light of the probable constitutional infirmity of these prior restraints, it is necessary to consider the subsequent punishment ${ }^{10}$ of either the purchaser or seller of term papers. Since "subsequent punishment" may also be subject to constitutional pitfalls, and because the desirability of legislative and judicial intervention has been

479 (1960), that " $[t]$ he vigilant protection of constitutional freedoms is nowhere more vital than in the community of American schools," id. at 487, the activities of the term paper companies appear to pervert rather than promote the principles of academic freedom.

6. Prohibitiou of the seller's conduct is seen as a means of inhibiting indirectly the conduct of the potential purchaser, by restricting severely his access to pre-existing or tailored term papers. Were it not for the extreme likelihood of future objectionable conduct by the purchaser of a term paper there would be no reason to attempt to prohibit or in any way restrict the operations of the sellers of term papers.

7. See notes 78-87, 108-111 infra and accompanying text.

8. With respect to term paper sales and plagiarism, Justice Douglas' remark in his dissent to Roth $v$. United States is apt: "Even the ill-starred Dennis case conceded that speech to be punishable must have some relation to action which could be penalized by government." 354 U.S. 476, 509 (1957).

9. See, e.g., New York Times Co. v. United States, 403 U.S. 713 (1971).

10. [T] systems of previous restraint on the right of free speech and penal laws imposing subsequent punishment on utterances and activities not within the anibit of the first Amendment's protection. Times Film Corp. v. Chicago, 365 U.S. 43, 53 (1961) (Warren, C.J., dissenting).

The argument against prior restraints and in favor of subsequent punishnent is stated succinctly by Blackstone:

The liberty of the press is indeed essential to the nature of a free state; but this cousists in laying no previous restraints upon publication, and not in freedom from censure for criminal matter when published. Every freeman has uudoubted right to lay what seutimeuts he pleases before the public; to forbid this, is to destroy the freedom of the press; but if he publishes what is improper, mischievious or illegal, he must take the consequences of his own temerity. W. BLACKSTONE, COMMENTARIES *151-52, quoted in Zenith Int'1 Film Corp. v. Chicago, 183 F. Supp. 623, 627 (N.D. Ill. 1960).

A memorandun circulated to the council of main campus deans at Georgetown University indicated an interest in both prior restraint aud subsequent punishment: "Georgetown will explore the possibilities both of injunctions before the fact and of possible damage suits in the event that acts of plagiarism can be traced back to such organizations." GU Seeks to End Paper Service, Georgetown Voice (student newspaper, Georgetown University), Feb. 22, 1972. 
seriously questioned, ${ }^{11}$ this Comment will recommend the revitalization of sanctions which might be imposed as a form of self-help by the academic community. ${ }^{12}$

\section{The Magnitude of the Problem}

The rapidity with which state legislatures have enacted term paper statutes is only one indication of the magnitude of the problem created by the existence of term paper companies. Because the ready availability of term papers ${ }^{13}$ is a strong temptation to even the most dedicated student, some professors now feel that the likelihood of receiving purchased term papers from their students is high enough that term papers ought not be assigned in their courses. ${ }^{14}$ Not only has the

11. Because plagiarism has traditionally been a form of academic misconduct against which sanctions have been applied only by the academic community itself, see notes 157-73 infra and accompanying text, it is doubtful that educators would support the statutory criminalization of plagiarism by state legislatures. Although states clearly have the power to discipline academic offenses, the wisdom of such discipline through criminal prosecutions rather than the application of locally tailored university sanctions is debatable. Moreover, state courts have both the power and the responsibility to review the imposition of academic sanctions for violations of procedural and substantive due process: "It is only of relatively recent date that courts have recognized the viability and impact of judicial review in student claims of constitutional infringement relating to university expulsion, suspeusion, or other disciplinary action." Schwartz, The Student, the University, and the First Amendment, 31 OHo ST. L.J. 635, 636 (1970). The new judicial attitude toward the regulation of student conduct by universities may come as a surprise to administrators accustomed to a less interested judicial observation of their actions: "[H]istorically the regulation of conduct within the university has been the handiwork of lawmakers who have had little reason to suppose that it would be subjected to constitutional scrutiny, at least in substantive terms." Soglin v. Kauffnian, 295 F. Supp. 978, 995 (W.D. Wis. 1968).

12. See notes 164-73 infra and accompanying text.

13. Term papers may be purchased locally or through the mails from companies which maintain tibraries of as many as 20,000 or more used papers on alnost any topic. "The bigger outfits have . . . installed such sophisticated equipment as facsimile transmission, so that a scholar in Los Angeles can dial up a ready-made dissertation prepared by a Harvard Ph.D." Cheating, Inc. 91, col. 1. "The clerk dials the firm's main office in Boston and then attaches the teleplione receiver to a copying machine. A few minutes later, page after page of an impressively researched paper, transmitted from Boston, rolls off the copier . . . [sic]" (italics omitted). TIME, Mar. 27, 1972, at 76, col. 3.

14. Academic Vice-President Thomas R. Fitzgerald, S.J., of Georgetown University has stated,

The very existence of these firms is creating a certain sense of mistrust between the faculty and the students and also between students themselves. I know of at least one faculty member who is not going to give a term paper this semester. GU Seeks, supra note 10.

The entrepreneurs of term paper companies have, predictably, a different attitude toward the assignment of termpapers:

A termpaper assignment is explicitly not designed as a grading device, nor as a means of forcing students to compete against each other. Nor is it a test of 
proliferation of term paper companies undermined the validity of a widely used educational tool, but also, more importantly, the largescale commercialization of plagiarism has focused attention on the legitimacy of the educational process itself. ${ }^{15}$

Unfortunately, because of the difficulty in obtaining accurate information about the sales volumes of individual companies, ${ }^{16}$ the true

any sort. Rather, its purpose (as any professor will confirm) is to provide the student with an opportunity for pursuing independent research-that is, it is meant to bo a learning experience. . [T] [The surprising popularity of the services offered by The Academic Marketplace and similar firms suggests that a considerable number of students do not always perceive termpaper assignments in this light .... It is my contention that The Academic Marketplace, by freeing the student from ["uninteresting and arbitrary burdens"], supplies a much-needed corrective to the educational process . . . tending thereby to improve both the quality of the education imparted to the individual student and the value received by the public in the form of qualified graduates. The services provided by The Academic Marketplace are therefore in the public interest, and should be acknowledged to be such. Respondent's Reply "Brief" at 1, Bruce Inksetter, No. 997 (Wis. Dep't of Agriculture, May 16, 1972).

15. "[T]he term paper industry is only one symptom that our educational system is in need of an overhaul." Letter from Hank Heyman, Letters, ChANGE, Winter 197273 , at 4 . Other commentators have been both more specific and more apocalyptic in their suggestions that term paper companies pose a serious threat to the academic community:

The challenge of the termpaper company transcends the simple old-fashioned attack on university regulations of skill and knowledge acquisition. . . . It raises questions about the changing role of the university in the community and, even more significantly, the place of education and the educated in this democratic enfranchised republic. Trachtenberg, What Happened to the Buffalo?, Change, Oct. 1972, 45, at 47.

16. The most likely sources of such information are student purchasers of term papers, faculty members to whom such papers are submitted, and the term paper companies themselves. However, due to the danger of academic sanctions and peer pressures against "informants," student-purchasers are not about to come forward with information. Memorandum of State of Connecticut in Support of Motion for Temporary Injunction at 2-3, State v. Papers, Inc. (Hartford County Sup. Ct., Conn., Dec. 8, 1972) (number unavailable).

"Faculty members can offer only opinions based upon their experiences but no firm empirical evidence." Id. at 3. One reported dialogue between a reporter and a professor of English went as follows: "How big a problem is this?' . . . 'Oh, it's very big. I don't have any figures, but there are dozens of companies advertising, so they must sell a lot of them.'" Rosenberg 137.

The only accurate figures are hikely to be those found in subpoenaed business records of term paper companies. In the future, though, such records may not be as complete as they have been found to be in the past: "According to a source close to the termpaper industry, Ken Warren, part owner of Termpapers Unlimited, urged the presidents of other termpaper firms to destroy all their business documents." Harvard Crimson, Oct. 21, 1972, at 4, col. 2. Destruction or concealment of business documents in which the names of student purchasers are listed has been the practice of some defendants: "After he had knowledge that the court had entered a restraining order, he [the defendant] went to his place of business and removed or caused to be removed his business files, including his security file, stating to bystanders something to the effect that he did not want authorities to get the kids' names." Memorandum of Board of Trustees in Support of Motion for Temporary Injunction at 2, Board of 
magnitude of the term paper business can only be estimated. ${ }^{17}$ Even speculation on this subject is impractical, since inost news accounts have been superficial in their analyses of the business structures ${ }^{18}$ and operat-

Trustees of the Ohio St. Univ. v. Term Papers Unlimited, No. 72CV-03-1010 (C.P., Franklin County, Ohio, April 21, 1972).

17. "It is difficult to assess statistically the extent to which students are using term paper companies. ... At this point the extent of patronage is speculative." Ambash, supra note 1, at 162 . TrMe has called the selling of term papers "a nationwido multimilliou-dollar business," but adds "there are no reliable figures on the number of fakes turned in every month . . .."ThME, Mar. 27, 1972, at 76, col. 3. A recent commentator has observed that "[h]ard figures are not easy to come by in this business . . . Rosenberg 134. The same commentator stated:

Even in states where no laws ban the selling of term papers, industry people are afraid of too much publicity about their dollar volume. Attorneys general don't much care, on the whole, about cheating in school-that, after all, is the school's lookout. But when the cheating is part of a multimilliondollar business, the secular arm of the law begins to twitch. Id.

18. The business structures of term paper companies vary considerably. Term paper companies do not publicize their business structures theinselves, except perhaps to potential affiliates. See Exhibit 10 to Complaint of State of Wisconsin at 3, 10, Bruce Inksetter, No. 997 (Wis. Dep't of Agriculture, May 16, 1972). Many, perhaps most, of the companies are quite small and advertise only locally:

To be sure, most of the term-paper companies are not what could be called successful in any couventional business sense of the term. Some, perhaps a majority, represent no more than the temporary efforts of a graduate student to capitalize his typewriter. These resemble nothing so much as the old fraternity files that were available to brothers in the market for prefabricated scholarship. Rosenberg 134.

But a few companies have advertised nationally: "Termpaper Arsenal of Los Angeles ... advertises as far east as Queens College in New York." Rosenberg 134. The largest of these companies are correctly referred to as "term-paper mills." Id.; TrMe, Mar. 27, 1972, at 76, col. 3. Such "term-paper mills" have "turned cheating on campus into a . . . well-organized enterprise." Cheating, Inc. 91, col. 1.

The largest companies are organized into a central office with some degree of supervisory or administrative control over a number of branch offices. Ward Warren Enterprises includes "a string of perhaps fifty offices located around campuses across the country ...." Rosenberg, 134-35. The Warren "organization" was once said, by Ward Warren, to employ "some 2,000 employees at 50 U.S. and Canadian branches . . . " Cheating, Inc. 91, col. 2. At one time, Ward Warren was "trying to expand his business into the untapped European market." Daily Tar Heel (student newspaper, University of North Carolina at Chapel Hill), Oct. 24, 1972 (column and page unavailable). Write-On, Inc., a Michigan term paper company, has been said to have "36 outlets in the Umited States and Canada." Steinway \& Karle 8. Sometimes such branch offices are run as quasi-franchise operations: "The bigger outfits have built up a coast-to-coast network of franchises to peddle their product . . . " Cheating, Inc. 91, col. 1. The Boston companies of Ward Warren seem to have attempted to create a relationship with their subsidiaries in which they have rented a Master List, in addition to their wholesale operation: "Let me add at this point, that the funds forwarded to Ward Warren Manuscripts, Inc. are not a deposit to be used for charging orders against. This is a rental fee for the use of the Master List." Exhibit 10 to Complaint of State of Wisconsin at 11, Bruce Inksetter, No. 997 (Wis. Dep't of Agriculture, May 16, 1972) (Schueler, Examiner).

It is not always evident who the parent company of a local term paper branch office is. American Copyrighting and Publishing Associates, a term paper conpany 


\section{ing procedures ${ }^{19}$ of the companies and have been confined to a treat-}

formerly in operation in Durham, North Carolina, sent all orders to "the main office in New Orleans." The name of the New Orleans company was also apparently American Copyrighting and Publishing Associates. The New Orleans company in turn routed orders to Termpapers Unlimited, a Ward Warren company in Boston. The Chronicle (student newspaper, Duke University), Oct. 6, 1972, at 4, col. 1; Feb. 8, 1973, at 1; Daily Tar Heel (student newspaper, University of North Carolina at Chapel Hill), Oct. 24, 1972 (column and page unavailable). A two-tier systein of branch operations or franchise units beneath an ultimate parent company offers unique insulation to the term paper entrepreneur. So far, no term paper company is known to have attempted a corporate organization with outside shareholders, though several companies have formed close corporations. Cases have been brought against such incorporated companies in Connecticut, Michigan, and New York.

19. The operating procedures of term paper companies vary as widely as their business structures. Some large companies are known to have used sophisticated transmission equipment to send term papers from office to office. See note 13 supra. Other companies have purchased an 800 telephone number "so that patrons across the country can call in their orders toll-free." Rosenberg 134. One company is said to "rotate its ... papers periodically around the country." Steinway \& Karle 9. Attenipts have also been made to avoid selling copies of the same paper from a company's master files to two students in the same course, a form of corporate solicitude that has been advertised as internal "quality control." The manager of one unidentified term paper company stated, "We have a system of checks and balances. We know where every paper has been, and we won't sell a paper to a student who goes to a school where the paper's been before. It's one of the ways we try to avoid plagiarism," (emphasis added). Einsiedler, Buying Term Papers, TOdaY's Educatron, September 1972, 44. Ward Warren Manuscripts wrote to one of its affiliates,

Services which we render that you may be unaware of are a set up means of Quality Control, records of where all papers have been throughout the country, an up-dating system to keep you aware of current changes in the master list, coinplaint department, and general up-keep of all systems. Exhibit 10 to Coinplaint of State of Wisconsin at 10, Bruce Inksetter, No. 997 (Wis. Dep't of Agriculture, May 16, 1972).

Original papers are written to precise student specifications. See State v. Saksniit, 69 Misc. 2d 554, 557-58, 332 N.Y.S.2d 343, 346-48 (Sup. Ct. 1972), for quotations from student specifications for individual papers. One student ordered and paid $\$ 65.73$ for an answer to a "take-home" final examination. Exbibit 6 to Complaint of State of Wisconsin, Bruce Inksetter, No. 997 (Wis. Dept. of Agriculture, May 16, 1972). The work of writing the papers is contracted out by the companies, often on a free-lance basis. Steinway \& Karle 8; Einsiedler, supra at 44; State v. Saksniit, 69 Misc. 554, 556, 332 N.Y.S.2d 343, 345 (Sup. Ct. 1972). Not all of the writers for the conıpany involved in Saksniit were amatenrs: "[T] indicates that many writers who did work for defendants were professional free-lance writers." Affidavit of Stephen Mindell at 4, State v. Saksniit, supra. Only the very small entrepreneur is likely to write papers himself. See note 16 supra. One commentator refers to such operators as "small businessm[e]n":

One professor reminisced about one of her classmates at a junior college in Missouri. The classmate, an excellent creative writer, went into business for herself writing term papers .... She analyzed a client's previous papers for his writing style and characteristic spelling and grammar errors. Then she produced a paper the buyer might have written-one that was slightly improved over his previous work ..... However, this young entrepreneur's business was so successful that she just didn't liave the time to prepare lier own papers-and flunked out of school. Einsiedler, supra at 45.

Conpanies are proud of the credentials of their anonymous writers: 
ment of the immediate local impact of the various operations. Present estimates of the volume of busmess being done by term paper companies thus may as easily reflect journalistic sensationalism as mathematical certitude. However, partial estimates could be based upon a number of factors, including (1) the number of campuses near which term paper companies operate or have operated, ${ }^{20}(2)$ the number of newspapers which carry advertisements for term paper companies and the frequency with which such advertisements appear, ${ }^{21}$ (3) the number

We have very reliable writers across the couutry, $\mathrm{Ph} . \mathrm{D}$.'s, professors, young assistant professors, grad students, even one visiting professor to MSU' [Michigan State Umiversity] from Oxford contributed to the cause. Some of our best writers are people who haven't finished college .... Statement by Arthur

Harger of Write-On, Inc., in Steinway \& Karle 8-9. Termpapers, Inc., a Washington, D.C., company, states on the reverse side of the order blank form it uses that it has a "Professional Staff of College Graduates." Chronicle of Higher Education, Mar. 6, 1972, at 4, col. 1. One Boston company has boasted in advertisements, "All papers written by published writers with M.A.'s." Wall Street Journal, Mar. 18, 1971, at 1, col. 5. Writers may even specialize, writing papers only in the field in which they have taken their degree or have done substantial course work. Einsiedler, supra at 44. Writers may be required to submit samples of their work in advance: "To write for Write-On, one is simply required to state his academic background, show at least three samples of written works and complete a sample assignment for which he is paid. A good writer can earn up to $\$ 300$ a week." Steinway \& Karle 9. Writers may also be required to assign copyright to the company on all papers which they write. Complaint of State of New York at 5, State v. Saksnit, 69 Misc. 554, 332 N.Y.S.2d 343 (Sup. Ct. 1972). The purpose of such a copyright provision is perhaps to prevent the writer of a paper from selling a copy of it to a rival term paper company. Writers may also be required to guarantee that the work they submit to a company is itself original. State v. Saksniit, 69 Misc. 554, 556-57, 332 N.Y.S.2d 343, 345-46 (Sup. Ct. 1972). Such a provision may be designed to prevent writers from themselves purchasing papers from students for a price higher than that which the company would pay to a student but lower thau the sum a company would pay to a writer for writing such a paper.

Even teachers and professors write for term paper companies; at least one instructor has anticipated with amusement the submission of one of his own works by a student for credit in a course taught by him:

You know what I used to think about? I used to think that someday a kid would turn in to me a paper I wrote. There were a couple of close calls, too. There were a few times when I wrote papers on books I was teaching in my class. But they turned out to be for someone else, I guess, because I never saw them. . . Waste of time if it happens, too, isn't it? I mean, if I knew I was going to be the one to read it, I could save myself the time of writing it. Really, thougb, I don't know wbat I'd do if it happened. I's like two respectable gnys running into each other coming out of a peep show on FortySecond Street. I guess they just pretend they didn't see each other. Rosenberg 136.

20. Today's Education, a publication of the National Education Association of the Umited States, sent questionnaires to "212 college and university officials" in order to learn, among other things, where term paper companies are located. One hundred officials responded to the questionnaires, and of these " 24 knew of a company in their area which sells research papers ...." Einsiedler, supra note 19, at 44 .

21. For obvious reasons most advertisements placed by term paper companies have appeared in college newspapers, but term paper advertisements have appeared in gen- 
of students on any one campus who are known to have purchased term papers, whether from local term paper companies or through the mails from other in-state or out-of-state companies, ${ }^{22}$ (4) the sales volumes of individual term paper companies, ${ }^{23}$ and (5) the amounts

eral public newspapers as well. Findings of Fact and Conclusions of Law at 2, Bruce Inksetter, No. 997 (Wis. Dep't of Agriculture, May 16, 1972). It is extremely difficult to compile information about the number of college newspapers in which term paper companies liave advertised, or the frequency with which companies have advertised in any one college newspaper. A file of back issues for a particular college newspaper is unlikely to be available outside the state in which the college is located, and even in the state may not be available outside the community in which the college is located. Several college newspapers have voluntarily stopped running term paper advertisements. Education U.S.A., Nov. 6, 1972, at 55. "The Daily Princetonian is one of the few college newspapers that refuse such advertisements." N.Y. Times, Feb. 13, 1972, at 54, col. 2. For the documentation of similar refusals, see Einsiedler, supra note 19 , at 46; Steinway \& Karle 11. The operator of one term paper company has cominented, "It's hard to spread the word . . " when local newspapers will not carry term paper advertisements. Daily Tar Heel (student newspaper, Umiversity of North Carolina at Chapel Hill), Oct. 24, 1972 (column and page unavailable).

22. Thirty students at Central Connecticut State College are thouglit to have purchased term papers. Chronicle of Higher Education, Jan. 15, 1973, at 3, col. 2. "In Wisconsin a 'restrictive hold' has been placed on the grades of 600 students who are suspected of having used purchased term papers in their degree work." CHANGE, supra note 15, at 46. Even when business records which do include the names of student purchasers are seized, though, it is not always possible to learn the number of students who have purchased term papers from a particular company. Although the county solicitor in Durham County, Nortli Carolina, used a search warrant to obtain the business records of American Copyrighting and Publishing Associates, a Durham term paper company, the solicitor is reported to have said,

'We were not interested in prosecution of the students and told them we would not disclose their names.' . . . He said he assured the students he 'would make sure their schools did not find out' about their dealings with the term paper service.

The Chronicle (student newspaper, Duke University), Feb. 8, 1973, at 8, col. 2.

23. The complaint in a case brought by the State of New York against a term paper company operating in New York City alleged "[t]hat in response to . . . advertising at least 965 students from over 100 different colleges purchased papers from defendants resulting in sales approximating $\$ 35,416$ between approximately November 1, 1971 and January 31, 1972." Complaint of State of New York at 4, State v. Saksniit, 69 Misc. 2d 554, 332 N.Y.S.2d 343 (Sup. Ct. 1972). An affidavit in Saksniit stated more particularly that most purchasers were from the New York City area, that some papers had been purchased by high scliool students, and that papers had been purchased for both graduate and undergraduate courses. Affidavit of Steplien Mindell at 5, State v. Saksniut, 69 Misc. 2d 554, 332 N.Y.S.2d 343 (Sup. Ct. 1972). WriteOn, a term paper company headquartered in East Lansing, Michigan, is said to liave "grossed an estimated $\$ 5$ million nationally" since its founding. Steinway \& Karle 8. Arthur Harger, the proprietor of Write-On, has stated, "We're turning over more than 4,000 pages a month," and estimates "that Write-On has sold approximately two nillion pages at $\$ 2$ to $\$ 4.50$ a page, depending upon the degree of originality." Id. Termpapers Unlimited, a conipany based in Boston, is said to be "the oldest and most prosperous ( $\$ 1.2$ million grossed in 1971) term paper firm." Daily Tar Heel (student newspaper, University of North Carolina at Chapel Hill), Oct. 24, 1972, at 1 
offered by prospective purchasers for the individual term paper companies. ${ }^{24}$ Any intelligent estimate of the magnitude of the term paper business should be based upon an awareness and consideration of all five factors listed above. No such estimate has yet appeared. The problem of determining the magnitude of the term paper business is further coinplicated by the fact that one company may operate under several nanies. ${ }^{25}$ Though the runaway success of term paper companies and the recent visibility of the plagiarism problem have spurred a genuine and legitimate concern, the interjection of first amendment protection may preclude an effective ban on term paper sales.

\section{Term Papers as Protected Speech UNDER THE FIRST AMENDMENT}

The preparation and sale of term papers involves not only written communication but also "pure speech," an exchange of ideas ar-

(column unavailable). See Cheating, Inc. 91, col. 2. Ward and Kenneth Warren, the proprietors of this Boston company, "estimate that more than 100,000 papers have been sold" and "reportedly did $\$ 1.8$ million of business last year." EDUCATroN U.S.A., Nov. 6, 1972, at 55 .

24. Termpapers of America, Inc., of Madison, Wisconsin, one of the "smaller firms," is said to have been sold by its owners for $\$ 1,400,000$. Daily Tar Heel (student newspaper, Umiversity of North Carolina at Chapel Hill), Oct. 24, 1972, at 1, col. 1. This report, however, was probably inaccurate:

Marty Pesham, a 23-year-old hustler who ran Termpapers of America, Inc., from an office in Madison, Wis., announced grandly some weeks ago that he was selling out for $\$ 1.4$ million to an unnamed "West Coast industrialist" and planned to go into semi-retirement. But he summoned the press again earlier this month to say that the deal was still hung up. "I'm in a very hazy situation now," he said mysteriously. A University of Wisconsin professor suggested one reason why, "After all," the professor noted, "no one wants to buy something today that becomes illegal tomorrow." Cheating Inc. 92, col. 1 .

Pesham has also been identified as the Manager of Termpapers Unlimited, also of Madison, Wisconsin. Daily Cardinal (student newspaper, University of Wisconsin at Madison), Feb. 1, 1972 (column and page unavailable).

25. It is apparent from both Saksniit in New York and Trustees of Boston University in Massachusetts that one business entity selling term papers may operate under several names at various times, and that an imdividual or group of individuals may operate noore than one term paper company at a time. Legal action is pending in Trustees of Boston University against seven sets of defendants operating eleven term paper companies in Boston. Furthermore, companies may attempt "to legitimize their operation by nodifying their name. ..." Letter from David Hoffman, Editor-inChief, The Review (student newspaper, University of Delaware) to Institute of Government, Chapel Hill, North Carolina, Feb. 16, 1973, citing one company which had changed its name to "Collegiate Research and Advisory Service." Such changes in nomenclature may become routime defensive tactics for term paper companies. Chronicle of Higher Education, July 30,1973, at 5, col. 1. No attempt has been made to compile a cumulative list of all term paper companies and the names under which they did or still operate. 
guably protectable under the first amendment. ${ }^{26}$ The Supreme Court has indicated that this protection extends to even the inost inarginal "exchanges of ideas." Justice Frankfurter conceded in his dissent to Winters v. New York $k^{27}$ that "[w]holly neutral futilities, of course, come under the protection of free speech as fully as do Keats' poems or Donne's sermons." The majority in Winters stated, with more enthusiasm, that even though the magazimes in question contained "nothing of any possible value," they were "as much entitled to the protection of free speech as the best of literature." 28 A term paper, arguably, is somewhat inore than a "[w]holly neutral futilit[y]" and is clearly entitled to as inuch constitutional protection as magazines which contain "nothing of any possible value to society."

Given the willingness of the judiciary to protect the most mundane forms of expression, it is surprising that the applicability of the first amendment to term paper distribution has engendered serious debate. Nevertheless, it has been argued that term papers should be treated under the Constitution as one would treat groceries or any consumer product. ${ }^{29}$ The argument presumably proceeds from the assumption that the written words embodied in such "academic" creations involve neither an exchange of ideas nor any expressive communication that the first amendment was designed to protect. The high prices charged for term papers allegedly provide evidence that the purchasers of term papers do not buy thein for legitimate reasons, ${ }^{30}$

26. Lurking in and around the domain of commercialized cheating are the precious rights of freedom of speech, of the press, and of distributing information. The task of drafting a statute is circumscribed by this often tenuous boundary; The law must proscribed cheating, yet leave protected speech intact. Ambash, supra note 1, at 164.

27. 333 U.S. 507, 528 (1948) (Frankfurter, J., dissenting).

28. Id. at 510 .

We do not accede to appellee's suggestion that the constitutional protection for a free press applies only to the exposition of ideas. The line between the informing and the entertaining is too elusive for the protection of that basic right. Everyone is familiar with instances of propaganda through fiction. What is one man's amusement, teaches another's doctrine. Though we can see nothing of any possible value to society in these magazines, they are as Id. at 510 . much entitled to the protection of free speech as the best of literature.

29. Defendants have been selling their papers for a price, a price quoted at so inuch per page. This fact alone clearly indicates that the purpose of defendants is not to communicate information, knowledge, or behiefs, but rather to sell a commodity just as a grocer would sell apples or a druggist would sell aspirin. The Supreme Court has recognized the distinction between commercial activities and the exercise of freedom of speech and press in cases arising under the First Amendment. Memorandum Contra Motion to Vacate, Terminate or Dissolve Temporary Restraming Order at 2, Board of Trustees of the Ohio St. Univ. v. Term Papers Unlimited, No. 72CV-03-1010 (C.P., Franklin County, Ohio, 1972).

30. In the context of obscenity, high prices may go to the issue of scienter: 
and indeed, it is probably true that many student patrons fail even to read their purchases. Despite the unique appeal of this line of reasoning, the language of a number of Supreme Court opinions clearly indicates that the Court would not sympathetically receive an attempt to deny first amendment protection on the grounds that term papers are sold only for profit and not to distribute information. ${ }^{31}$ Furthermore, payment by the purchaser is as irrelevant as the seller's profit. ${ }^{22}$ In this vein, the Supreme Court recently reiterated its intent to protect the exchange of written ideas regardless of the quality of that communication: "Above all else, the First Amendment means that government has no power to restrict expression because of its message, its ideas, its subject matter, or its content."33

"The evidence of scienter in this record consists, in part . . . of the exorbitant prices marked on the books." Mishkin v. New York, 383 U.S. 502, 511-12 (1966).

31. The Supreme Court stated in Ginzburg v. United States, 383 U.S. 463 (1966), No weight is ascribed to the fact that petitioners have profited from the sale of publications which we have assumed but do not hold cannot themselves be adjudged obscene in the abstract; to sanction consideration of this fact might indeed induce self-censorship, and offend the frequently stated principle that commercial activity, in itself, is no justification for narrowing the protection of expression secured by the First Amendment. Id. at 474.

See also Pittsburgh Press Co. v. Pittsburgh Comm'n on Human Relations, 413 U.S. 376, 384-85 (1973). Smith v. California, 361 U.S. 147, 150 (1959); Cammarano v. United States, 358 U.S. 498, 514 (1959); Joseph Burstyn, Inc. v. Wilson, 343 U.S. 495, 501-02 (1952). But see Barron, Access to the Press-A New First Amendment Right, 80 HARV. L. REv. 1641 (1967): "The usefulness of Ginzburg lies in its recognition of the doctrine that when commercial purposes dominate the matrix of expression seeking first amendment protection, first amendment directives must be restructured." Id. at 1663.

But see Louisiana State University Board of Supervisors v. Lewark, - La. -

So. 2d (1973) (Dixon, J., concurring); Barron, supra, at 1663. In Lewark, which may have been erroneously decided, a distinction was drawn between first amendment protection of material such as political hterature when sold and when distributed free: "This is not a First Amendinent case because the students have been enjoined only from selling the material on uuiversity property; they are not prohibited from otherwise distributing political literature on the campus." - La. at -, - So. $2 \mathrm{~d}$ at - .

32. Time, Inc. v. Hill, 385 U.S. 374, 397 (1967); New York Times Co. v. Sullivan, 376 U.S. 254, 266 (1964).

33. Pohice Dep't v. Mosley, 408 U.S. 92, 95 (1972). The Brief for the Umited States in New York Times Co. v. United States, 403 U.S. 713 (1971), noted that there was in that case no "attempt to impose a generalized probibition upon the pubfication of broad categories of material," as if such a general prohibition would clearly be nnconstitutional. Id., Brief for the United States at 7. More recently, in Branzburg v. Hayes, 408 U.S. 665 (1972), the Court stated that

the First Amendment ordinarily prohibits courts from inquiring into the content of expression, except in cases of obscenity or libel, and protects speech and publications regardless of their motivation, orthodoxy, truthfulness, timeliness, or taste .... By affording a privilege to some organs of communication but not to others, courts would inevitably be discriminating on the basis of content. Id. at 705 n.40 (citations omitted). See also Cohen v. California, 403 U.S. 15, 19 (1971). 
The argument might also be advanced that term papers are a regulable "method" or "form" of communication. Certain forms of communication, most notably labor picketing, are accorded less than full first amendment protection for the reason that they involve simultaneous speech and conduct. ${ }^{34}$ But there is no conduct in the sale of a term paper which may be given any more relevance, constitutionally, than the conduct of a bookseller who sells a book or pamphlet which is not obscene. ${ }^{85}$ Though it may be suggested that the copying of term papers is "conduct" as opposed to "speech," freedom of the

Like non-obscene content, the form in which written material is presented to its potential audience may not be considered as grounds for an exemption from first amendment protections. Indeed, to Justice Harlan, concurring in Roth v. United States, 354 U.S. 476 (1957), obscenity itself was not to be regarded as a separate form of literature, but rather the "suppression of a particular writing or other tangible form of expression [was to be] an individual matter ...." Id. at 497. A California court, in striking down a Los Angeles county ordinance banning the sale of crime comic books to children under 18 noted: "the exemption provided for newspaper comic strips is without justification .... [T] he exemption is based solely on the nature of the product produced on paper." Katzev v. County of Los Angeles, 52 Cal. 2d 360, 370, 341 P.2d 310, 316 (1959), quoted in Police Comm'n v. Siegel Enterprises, Inc., 223 Md. 110, 130, 162 A.2d 727, 737, cert. denied, 364 U.S. 909 (1960). If the sale of term papers might be prohibited on the basis of their form alone, then a state might equally be able to prohibit the sale or distribution of sonnets on the basis of some objection to their usual and predictable fourteen-line form, or the writing and distribution of hymnals and valentines or any other literary material characterized chiefly by its form rather than its content. But see Cohen v. California, 403 U.S. 15 (1971), in which the Court referred to "those relatively few categories of instances where prior decisions have established the power of government to deal more comprehensively with certain forms of individual expression simply upon a showing that such a form was employed" (emphasis added). Id. at 19-20.

34. An extreme position which would permit an assessment of the relative importances of speech and conduct in any action sought to be regulated is represented by Giboney v. Empire Storage \& Ice Co., 336 U.S. 490 (1949): "[]t has never been deemed an abridgment of freedom of speech or press to make a course of conduct illegal merely because the conduct was in part intiated, evidenced, or carried out by means of language, either spoken, written, or printed." Id. at 502. Though such a position is defensible if confined strictly to subsequent punishment, in at least one term paper case a similar argument has been proffered in support of an injunctive prior restraint: "Bank robbery is unlawful despite the fact that the robber gives his instructions to the teller written on a slip of paper. Freedom of speech or the press is not the issue in the present case." Memorandum Contra Motion to Vacate, Terminate or Dissolve Temporary Restraining Order at 6, Board of Trustees of the Ohio St. Univ. v. Term Papers Unlimited, No. 72CV-03-1010 (C.P., Franklin County, Ohio, filed May 16, 1972).

35. See note 26 supra. One might argue that term paper companies, which take requests for papers on a given subject matter and either produce or retrieve such papers, are engaged in "conduct" cognizable under the first amendment. But this would seem to be conduct essentially undistinguishable from that of the bookseller who receives a request for a book of a certain type or on a certain subject matter and then through references, knowledge, or experience supplies a suitable title. 
press is "a generic term embracing all means of mass communication of ideas." 36 The intervention of the copying machime between seller and purchaser would seem to be constitutionally equivalent to the intervention of the mechanical printing press between an author and publisher, on the one hand, and the ultimate reader of the written work on the other. Certainly it has never been suggested that a handwritten or typed work is entitled to more or less first amendment protection than a printed work. Even if "conduct" niay be involved in the term paper process, it seems reasonable to conclude that the labor picketing cases merely adjust, in one particularized context, the line which constitutionally distinguishes conduct from speech. ${ }^{37}$

Since term papers are therefore arguably subject to full first amendment protections, it next becomes necessary to examine the specific legislative and judicial responses to the plagiarism problem to determine whether they constitute prior governmental restraints on that protected speech.

\section{Governmental Reactions as Prtor Restraints}

The commercial term paper company, described by one commentator as "a corporate forin of the old fraternity files,"38 is a recent phenomenon. ${ }^{39}$ Similar, although smaller, enterprises are thought to

36. Miller, Principles of Law Limiting Radio Broadcasting, 9 F.R.D. 217, 221 (1950). The Supreme Court has, since Lovell v. City of Griffin, 303 U.S. 444 (1938), given "liberty of the press" a broad definition. Not only does "liberty of the press" apply to newspapers and periodicals, but it necessarily embraces pamphlets and leaflets. "The press in its historic connotation comprehends every sort of publication which affords a vehicle of information and opinion." Id. at 452.

37. While there may be good reason for not giving all forms of expression the same amount of protection, such a dichotony should not be overemphasized; there can be no such thing as "pure speech." As a scholar in the field poimts out: "[A]ll speech is necessarily speech plus. If it is oral, it is noise and may interrupt someone else; if it is written, it may be litter." The only true line between what is and what is not subject to regulation lies between beliefs and ideas, on the one hand, and actions of any form, on the other.

Note, First Amendment Rights-Flag Burning as Symbolic Action, 48 N.C.L. REv. 328, 333 (1970), quoting H. Kalven, The Negro and the FIRST AMENDMENT 201 (1965).

38. Martin Benjamin, Assistant Professor of Philosophy, Michigan State University, quoted in Steinway \& Karle 10. The fraternity files analogy has been widely used: "There was a time when cheating in college was largely an individual enterprise, aided at best by a tattered file of term papers and book reports collected over the years and carefully husbanded in the fraternity-house library." Cheating, Inc. 91, col. 1. See also Rosenberg 134; Editorial, Mich. St. News (student newspaper, Michigan State University), Mar. 5, 1973 (column and page unavailable). There are indications that the earhest of the term paper statutes, the North Carolina statute enacted in 1963, may have been passed to control, in part, the overuse of fraternity files. See note 51 infra.

39. Evidence of this is provided by the fact that there are no references to either 
have operated in the early 1960 ' $\mathrm{s}^{40}$ and perhaps even as long ago as the 1920 's, ${ }^{41}$ but only the recent term paper companies have aroused the level of comment and indignation ${ }^{42}$ necessary to sustain a twopronged attack in state legislatures ${ }^{43}$ and in the courts. Since 1963, legislation has been enacted or proposed in at least nine states. ${ }^{44}$ Local ordinances have also been proposed as a means of combatting the term paper epidemic, ${ }^{45}$ and brief consideration is said to have been

term papers or plagiarism in K. AleXander \& E. Solomon, College AND UNIverstry LAW (1972).

40. Cheating, Inc. 91, col. 2.

41. One Columbia graduate recalled the term-paper mills along Amsterdam Avenue in New York City in the Twenties, businesses that bought and sold used papers. Another spoke of the similar estabhshments near Harvard in the early forties-companies which were only whispered of and which, for the 19 , at 44 .

most part, only the affluent could afford to frequent. Einsiedler, supra note

42. Even the New York City police department has felt the compulsion to warn "all policemen taking college courses that purchasing term papers is 'unethical." Chronicle of Higher Education, May 1, 1972, at 3, col. 4.

43. The coverage of the statutes is not limited to term papers. Other specific or general forms of academic work listed in various statutes are: book reports (Illinois), theses (California, Colorado, Connecticut, Illinois, Maryland, New York, North Carolina), dissertations (California, Colorado, Connecticut, Illinois, Maryland, New York, North Carolina), essays (Connecticut, Illinois, Maryland, Massachusetts, New York), reports (Connecticut, Maryland, New York), themes (Illinois), "other manuscripts" (Massachusetts), "other written assignment[s]" (Connecticut, Maryland, New York), "other academic paper[s]" (Illinois), and "other written material" (California, Colorado).

In addition, North Carolina prohibits impersonating another student to take an examination. Impersonation in order to take an examination is hardly a uniquely American phenomenon. Recently a Russian who specialized in taking exams for others, and whose clientele was so large he was forced to hire associates, was given a 13-year prison sentence. N.Y. Times, Sept. 25, 1973, at 34, col. 1.

44. See, e.g., Cal. Educ. Code $\$ \$ 22530-35$ (West Supp. 1973); Pub. Act 3-581 (1973 West's Conn. Legis. Serv., No. 5); Ill. ANN. STax. ch. 144, § 219 (Smith-Hurd Supp. 1973-74); Md. AnN. Code art. 77A, $\$ 70$ (Supp. 1972); Mass. Crim. Code ch. 266, \& 33 (1972 Proposed Crim. Code with Revision Comm'n Notes); N.C. GEN. StaT. § 14-118.2 (1969); N.Y. EDUc. LaW § 213(b) (McKinney Supp. 1973-74); "A Bill for an Act Concerning the Practice of Dealing in Academic Materials," Senate Bill 30 (introduced by Senator L. Fowler), General Assembly, State of Colorado (1973). Term paper legislation is also being considered but has not yet been proposed in Michigan. Letter from Roderick K. Daane, General Counsel, The University of Michigan at Ann Arbor, to Institute of Government, Chapel Hill, North Carolina, Mar. 26, 1973.

45. The city council would do its student electorate a great service by banning term paper companies from the city limits. Such a local remedy would admittedly provide only a temporary solution. Even if the City of Lansing and Meridian Township were to enact similar ordinances, the term paper hucksters would soon find some other haven from which to carry out their transactions. A city ordinance might, however, provide some rehef until the legislature could act on a comprehensive state statute. Editorial, Michigan

St. News (student newspaper, Michigan State University), Mar. 7, 1972 (column and 
given to federal legislation. ${ }^{46}$ Furthermore under a variety of common law theories or under statutes intended originally to regulate other conduct, numerous actions have been brought against term paper coinpanies. ${ }^{47}$ If the production and sale of term papers involves protected speech, however, the sanctions inost frequently imposed on term paper companies raise the spectre of prior restraints on the exercise of first amendment rights. To facilitate the examination of these governmental responses, they may be divided into six general categories: (1) direct statutory proscription, (2) the prohibition of term paper advertising, (3) allegations that the operation of such enterprises involves unfair trade practices, (4) claims that term paper services constitute tortious interference with a contract, (5) imdirect attacks on the corporate status of term paper companies, and (6) actions based upon statutory and common law fraud.

\section{Direct Statutory Prior Restraints}

Even though no two existing term paper statutes are precisely

page unavailable). There is still no state statute in Michigan. See note 44 supra. But cf. Schneider v. State, 308 U.S. 147, 160 (1939):

Although a municipality may enact regulation in the interest of the public safety, health, welfare, or convenience, these may not abridge the individual liberties secured by the Constitution to those who wish to speak, write, print or circulate information or opinion.

46. "The possibility of new federal laws prohibiting interstate commerce in termpapers was raised in Congress and remains under lively consideration." CHANGE, supra note 15 , at 46.

47. See, e.g., United States v. International Term Papers, Inc., 351 F. Supp. 76 (D. Mass. 1972), judgment vacated and cause remanded, 477 F.2d 1277 (1st Cir. 1973); State v. Papers, Inc. (Super. Ct., Hartford County, Conn., filed Dec. 6, 1972) (number unavailable); Trustees of Boston Univ. v. Champion Research Corp., Equity No. 96114 (Super. Ct., Suffolk County, Mass., filed Oct. 19, 1972); Kelley v. Write-On, Inc., No. 7476 (Cir. Ct., Washtenaw County, Mich., filed Feb. 23, 1973); State v. Saksniit, 69 Misc. 2d 554, 332 N.Y.S.2d 343 (Sup. Ct. 1972); Board of Trnstees of the Ohio St. Univ. v. Term Papers Unlimited, No. 72CV-03-1010 (C.P., Franklin County, Ohio, filed May 16, 1972); Bruce Inksetter, No. 997 (Wis. Dep't of Agriculture, May 16, 1972). An unsuccessful suit was brought by the Attorney General of Louisiana against a term paper company under the Louisiana fair trades and practices act, which was held not to apply to the case. Letter from Homer L. Hitt, Chancellor, Louisiana State University in New Orleans, to Institute of Government, Chapel Hill, North Carolina, Oct. 10, 1973. See Chronicle of Higher Education, July 30, 1973, at 5 , col. 3 .

But term paper companies are not always defendants. A company in Washington, D.C. lias brought suit against a comic strip, alleging defamation of character: "[The "Steve Roper" comic strip] recently portrayed the operators of a term-paper company arranging for the murder of a professor lobbying for legislation to outlaw such businesses." Chronicle of Higher Education, Oct. 30, 1972, at 5, col. 1. 
identical, ${ }^{48}$ statutory prohibitions typically extend to the preparation ${ }^{40}$ of term papers for sale, the advertising ${ }^{50}$ of term papers for sale, the sale $^{51}$ itself of term papers, the transfer ${ }^{52}$ of term papers (presumably from one term paper company to another), and more rarely the possession $^{53}$ of term papers with the intent to sell or transfer. The sanctions against term paper companies for engaging in these proscribed activities vary widely from statute to statute. The Califorma statute, as well as the proposed Colorado statute patterned after it, provides for "such relief as is necessary to enforce the provisions of this chapter including the issuance of an injunction." not go so far, but similarly provides an injunctive remedy. ${ }^{55}$

48. See statutes cited at note 44 supra. The Connecticut statute is patterned after the New York statute which is itself an expansion of the Maryland statute. The proposed Colorado statute is virtually a copy, with minor amendments, of the California statute. The Illinois, North Carolina, and Massachusetts statutes are not related to each other or to the aforementioned statutes.

49. "Preparation" encompasses the following conduct: "prepare" (Cal., Colo., Conn., Mass.); "cause to be prepared" (Cal., Colo., Conn.); "author" (Mass.); "write" (Mass.); "assist" (N.C.); "attempt to assist" (N.C.); "preparation for sale" (III.).

50. "Advertising" provisions also prohibit: "offer[s] to prepare" (Cal., Colo., Conn.); "advertis[ing]" (N.C.); "offer[s] . . . to assist" (N.C.); "advertising for sale" (III.); "offer[ing] for sale" (Conn., MIl., Md., N.Y.).

51. Not only has "sell[ing] been outlawed (Cal., Colo., Conn., Ill., Md., N.Y.), but enterpreneurs have also been foreclosed from "otherwise distribut[ing]" (Cal., Colo.) or "assist[ing]" (N.C.). Only the earhest of the term paper statutes, N.C. GEN. STat. $\$ 14-118.2$ (1969), a statute enacted before the advent of large-scale coininercial term paper companies, fails to prohibit explicitly the sale of such academic creations.

52. Various term paper statutes prevent a term paper holder from "transfer[ing]" (Mass.); "otherwise distribut[ing]" (Cal., Colo.); or "sell[ing] . . . to any person who sells" (N.Y.). These provisions cover the action by which one term paper company might acquire copies of term papers in the files of another company, or the action by which a term paper company might acquire a paper from a free-lance writer of term papers.

53. The Massachusetts statute, which includes the words "possesses with intent to sell or transfer," has been proposed in the state which has been most plagued by the activity of term paper companies and the state in which the most successful franchisor, Ward Warren Enterprises, has been headquartered.

54. CaL. Educ. Code ch. 1.7, \& 22532 (West Supp. 1973); "A Bill for an Act Concerning the Practice of Dealing in Academic Materials," Senate Bill 30 (imtroduced by Senator L. Fowler), General Assembly, State of Colorado (1973). The California statute, closely followed in language by that proposed for Colorado, goes on to provide that "[n]othing in this chapter shall be construed to preempt or in any other way linit, dinninish, or imply the absence of rights of any party, public or private, against any person in connection with any of the acts described ..." CAL. EDUc. CODE ch. 1.7, \& 22534 (West Supp. 1973).

55. Ill. ANn. Stat. ch. 144, § 219 (Smith-Hurd Supp. 1973-74). Both the Connecticut and New York statutes also provide for injunctions. CoNN. GEN. STAT. ANN., P.A. 73-581 (1973 West's Conn. Legis. Serv., No. 5); N.Y. Educ. LaW § 213 (b) (McKinney Supp. 1973-74). 
Inasmuch as the first amendment arguably extends to the authorship ${ }^{56}$ and distribution ${ }^{57}$ of term papers, injunctions and statutory language expressly prohibiting "preparation" or "sale" clearly constitute direct prior restraints. The Supreme Court has also labeled as prior restraints all governmental actions which have the effect of preventing speech in advance. ${ }^{58}$ It is in the context of this latter definition that the remaining five statutory and common law restraints will be considered.

\section{Prohibitions on Term Paper Advertising}

Assuming for the moment that a state may not constitutionally prohibit the sale of term papers, may it nonetheless constitutionally prohibit the advertising of term papers? ${ }^{50}$ The answer is by no means clear. The Supreme Court first denied free speech protection to "commercial advertising" in Valentine v. Chrestensen." The Court in Valentine distinguished "communicating information" and "disseminating opinion" from "purely commercial advertising." Despite

56. See notes 27-28 supra and accompanying text.

57. The Supreme Court stated in Martin v. Struthers, 319 U.S. 141 (1943), that the freedoin guaranteed by the first amendment "enbraces the right to distributo literature . . . and necessarily protects the right to receive it." Id. at 143. The Court further stated in Martin that the freedom to distribute information to every willing citizen "is so clearly vital to the preservation of a free society that, putting aside reasonable police and liealth regulations of time and manner of distribution, it must be fully preserved." Id. at 146-47. In Griswold v. Connecticut, 381 U.S. 479 (1965), the Court subsequently stated that government could not act to contract the spectrun of available knowledge:

The right of freedoin of speech and press includes not only the right to utter or to print, but the right to distribute, the right to receive, the right to read ... and freedom of inquiry, freedom of thought, and freedom to teach ... indeed the freedom of the entire university community. Id. at 482 .

Lamont v. Postmaster Gen., 381 U.S. 301 (1965) also supports the fundamental right of an individual to receive, without governmental intervention or observation, materials entitled to first amendment protection: "It would he a barren marketplace of ideas that had only sellers and no buyers." Id. at 308 (Brennan, J., concurring). See also Stanley v. Georgia, 394 U.S. 557, 564 (1969).

58. See Bantam Books v. Sullivan, 372 U.S. 58 (1963).

59. At least one term paper company has advertised for writers. The following advertisement appeared in the Sunday, November 28, 1971 New York Times: " $\$ 115$. The Wizard of $\mathrm{Oz}$. / Its recent college graduate / who can research, write and/type papers for mdtn firm." Affidavit of Stephen Mindell at 3, State v. Saksniit, 69 Misc. 2d 554, 332 N.Y.S.2d 343 (Sup. Ct. 1972).

60. 316 U.S. 52 (1942) (conviction for advertising the exhibition of a submarine). In his concurring opinion to Cammarano v. United States, 358 U.S. 498 (1959), Justice Douglas stated that the Chrestensen opinion had been "casual, almost offhand," and suggested that it had "not survived reflection." $1 d$. at 514. But if interred, it has experienced a strong resurrectiou in Pittsburgh Press Co. v. Pittsburgh Comm'n on Human Relations, 413 U.S. 376 (1973).

61. 316 U.S. at 54. 
the recognition that states cannot "unduly burden or proscribe" the "privilege" of publicly broadcasting information or opinion, it was "equally clear that the Constitution imposes no such restraint on government as respects purely commercial advertising." ${ }^{2}$

However, whereas the commercial advertising cases restricted advertising as to place, time, medium of communication, or method of distribution, the term paper statutes attempt to prevent the advertisement of one product by all means, at all locations, and through all media - a total prohibition of any advertising of term papers. ${ }^{63}$ The realities of such a situation should compel a court to recognize that an "absolute prohibition of advertisements for [a] book might be tantamount to a prohibition of the book," 44 a form of secondary prior restraimt. Thus, if the sale of a book or term paper may not be constitutionally prohibited, the state sliould likewise not be able to ban book or term paper advertisements. ${ }^{65}$ A logical conclusion would extend this first amendment protection to the commercial advertisements of any item the preparation or sale of which would also be constitutionally protected. ${ }^{66}$ This would in turn require that courts distinguish

62. Id. Justice Douglas has taken the opposing view that the first amendment prevents any constitutional regulation of commercial advertising: "But there can be no valid law censoring the press or punishing it for publishing its views or the views of subscribers or customers who express their ideas in letters to the editor or in want ads or other commercial space." Pittsburgh Press Co. v. Pittsburgh Comm'n on Human Relations, 413 U.S. 376, 398 (1973) (Douglas, J., dissenting). But even Douglas concedes that "the press, like any other business, can be regulated on business and economic matters." Id. at 2564.

63. One recent Supreme Court case, Head v. New Mexico Bd. of Examiners in Optometry, 374 U.S. 424 (1963), might have produced a definitive statement by the Court on this issue, but the issue was not reached in the case. In Head a New Mexico statute prohibiting the advertising of prices of eyeglasses was permitted to be "enforced against radio broadcasters equally with other newsinedia doing business in New Mexico." Id. at 448 (concurring opinion). In this concurring opinion Justice Brennan stated:

The New Mexico law is one designed principally to protect the State's consumers against a local evil by local application to forbid certain forms of advertising in all mass media. Such legislation, whether concerned with the health and safety of consumers, or with their protection against fraud and deception, embodies a traditional state interest of the sort which our decisions have consistently respected. Id. at 445 .

The Court did not reach the previously unpresented issue as to whether an injunction under the statute would constitute "an invalid restraint upon freedom of speech." Id. at 433 n.12.

64. Developments in the Law-Deceptive Advertising, 80 HARV. L. REV. 1005, 1032 (1967).

65. "Even assuming that such a regulation could be justified as a question of substantive due process, such a restriction would probably be struck down as an unreasonable infringement on the protected speech represented by the books themselves." Id. at 1037.

66. For an argument that first amendment protection should be afforded FTC- 
between the advertisement of material which is itself actually or arguably protected by the first amendment and the advertisement of material which is clearly not protected in any way by the first amendment. A newspaper advertisement extolling the virtues of Norman Mailer's latest book, for example, would be entitled to greater constitutional protection than a used car layout. The courts have not yet made this distinction, but such a case has yet to arise in the term paper context. ${ }^{07}$

\section{Unfair Trade Practices}

The prohibition of term paper company operations as unfair trade practices would seem to be a third type of prior restraint on term paper companies. ${ }^{68}$ Only one case ${ }^{69}$ has thus far been brought against a term paper company on an unfair trade practices theory. In a recent administrative proceeding before the Wisconsin Department of Agriculture, a hearing examiner declared the sale of term papers "an unlawful activity"70 in violation of Wisconsin's "Little FTC Act." 11 Since the Wisconsin statute was modeled after section 5 of the Federal Trade Commission $\mathrm{Act}^{72}$ and since FTC rulings had been previously relied upon by the Wisconsin Department of Agriculture, ${ }^{73}$ the hearing examiner proceeded from the FTC's mandate "to create new bod[ies] of law" ${ }^{4}$ by considering "public values beyond simply those enshrined

mandated corrective advertisements and counteradvertisements, as well as "true" product information, see Note, The Pfizer Reasonable Basis Test-Fast Relief for Consumers But a Headache for Advertisers, 1973 DUKE L.J. 563, 592-93.

67. But cf. Breard v. Alexandria, 341 U.S. 622, 650 (1951) (Black, J., dissenting). Recently, in Pittsburgh Press Co. v. Pittsburgh Conm'n on Human Relations, 413 U.S. 376 (1973), the Court stated that "illegal commercial activity" is subject to a degree of regulation which permits a total prohibition on the advertisement of such an activity. Thus, if the sale of the term papers could constitutionally be made an illegal activity, the advertisement of term papers for sale could also be prohibited. If, on the other hand, as is argued herein, any prohibition on the sale of term papers would be a constitutionally impermissible prior restraint, then the question whether the advertising of term papers may be restricted or prohibited is more difficult to answer.

68. See, e.g., 15 U.S.C. \& 45(a) (1970) ("Unfair methods of competition in commerce and unfair or deceptive acts or practices in commerce are declared unlawful."); WIS. STat. $\$ 100.20$ (1967) ("Unfair methods of competition in business and unfair trade practices in business are hereby prohibited . . . .")

69. Bruce Inksetter, No. 997 (Wis. Dep't of Agriculture, May 16, 1972).

70. Id. at 13.

71. See note 68 supra.

72. See note 68 supra.

73. Bruce Inksetter, No. 997, at 9 (Wis. Dep't of Agriculture, May 16, 1972); Brief of the State of Wisconsin at 5, Bruce Inksetter, No. 997 (Wis. Dep't of Agriculture, May 16, 1972).

74. 29 Fed. Reg. 8324, 8349 (1964); All-State Indus., [1967-1970 Transfer Binder] TRADB REG. REP. If 18,740, at 21,105 (FTC 1969). 
in the letter or encompassed in the spirit of the antitrust laws."75 Viewing the questionable activities of the involved company as "one aspect of fraud in its broadest sense," "' the hearing examiner had hittle difficulty in denouncing the illegal "unfairness" of term paper operations. ${ }^{77}$ On the strength of the finding that the term paper company had committed unfair trade practices, an injunction was issued forbidding the respondent from advertising, preparing, or selling term papers-the classic form of prior restraint.

\section{Tortious Interference with a Contract}

In several pending term paper cases, ${ }^{78}$ a defendant term paper company is alleged to have tortiously interfered with a contract between the student purchaser of a term paper and the academic institution in which the student is enrolled. ${ }^{79}$ The plaintiffs in these cases

75. FTC v. Sperry \& Hutchison Co., 405 U.S. 233, 244 (1972), quoted in Bruce Inksetter, No. 997 (Wis. Dep't of Agriculture, May 16, 1972).

76. Bruce Inksetter, No. 997 (Wis. Dep't of Agriculture, May 16, 1972).

77. The examiner based his opinion upon, among others, the following grounds: (1) Term paper businesses take undue and unfair advantage of student weaknesses, and aid, abet and encourage the student to commit a fraud on the public at large, as well as on the school he attends. (2) The educational institution is deceived into believing that the paper represents the student's own work and, as a consequence, unfairly awards course credit to the detriment of other students and the educational process itself. (3) They foster an unequal and unfair relationship between students who use such services and those who do not. (4) They are unfair to einployers who select employees on the basis of educational records. (5) Term paper services unfairly compete with those organizations engaged in the publication and sale of legitimate student aids or study guides, as opposed to finished products for submission as the student's own work. Bruce Inksetter, No. 997 (Wis. Dep't of Agriculture, May 16, 1972). Because the scope and breadth of this jurisdiction under the Wisconsm unfair trade practices statutes was "equally as broad as that of the FTC as set forth in numerous federal case precedents," the examiner felt free to examine "new or different practices ... as they arise in the light of the circumstances," aud to find the practices of the term paper company objectionable. Id. at 9, quoting FTC v. R.F. Keppel \& Bros., 291 U.S. 304 (1934).

78. State v. Papers, Inc. (Super. Ct., Hartford County, Conn., filed Dec. 8, 1972) (number unavailable); Trustees of Boston Univ. v. Champion Research Corp., Equity No. 96114 (Super. Ct., Suffolk County, Mass., filed Oct. 19, 1972); Board of Trustees of the Ohio St. Univ. v. Term Papers Unlimited, No. 72CV-03-1010 (C.P., Franklin County, Ohio, filed May 16,1972 ) (the only term paper case in which first amendment issues have been raised).

79. The brief of the State of Connecticut in Papers, Inc., argues that a contractual relationship is formed when a person is granted the privilege to enter a state educational institution, and that the resulting student-university relationship may be terminated by the university if the student fails to perform satisfactorily or engages in serious misconduct. The State's brief refers vaguely to the "common law of education" to support the existence of such a relationship based on such a rationale. Memorandum of Law in Support of Motion for Temporary Injunction at 5-7, State v. 
assume that the contract supposedly existing between student and institution $^{80}$ requires the student to follow rules and regulations validly promulgated by the school. ${ }^{81}$ Such rules and regulations typically prohibit plagiarisin or similar academic misconduct. Accordingly, the student who purchases a term paper and uses it to commit plagiarism has breached his contract with the school, and the tern paper company which sold the paper to him has tortiously interfered with the same contract.

Use of a contract theory to explain the relationship between a student and the school which he attends has been seriously questioned,,$^{82}$ and at least one court has expressly repudiated the idea. ${ }^{83}$ Such a contract may be adhesionary because of the disparity in bargaining position between student and umiversity when the contract is entered into, and because of the power typically reserved by a umiversity to determine both when and whether the contract has been breached. ${ }^{84}$ Furthermore, a relationship which is viewed by the same courts as contractual for some purposes might be viewed by the courts as noncontractual for others. ${ }^{85}$ While recognizing a university's contractual authority to discipline a student, a court might at the same time deein the relation-

Papers, Inc. (Super. Ct., Hartford County, Conn., filed Dec. 8, 1972) (number unavailable). The defendants in a Massachusetts term paper case are alleged to have been "interfering with the contractual and advantageous relationships between Trustees of Boston University and its students" and "tortiously interfering with the educational functions and programs of Trustees of Boston University." Bill of Trustees of Boston University for Declaratory Judgenent at 1, Trustees of Boston Univ. v. Champion Research Corp., Equity No. 96114 (Sup. Ct., Suffolk County, Mass., 1972). Similar allegations with respect to an Ohio term paper company are made in the opening four paragraphs of the complaint in Board of Trustees of the Ohio St. Univ. v. Term Papers Unlimited, No. 72CV-03-1010 (C.P., Franklin County, Ohio, filed May 16, 1972).

80. See generally Note, Contract Law and the Student-University Relationship, 48 IND. L.J. 253 (1973).

81. See note 167 infra and accompanying text.

82. See Schwartz, supra note 11, at 637-38; Comment, Private Government on the Campus-Judicial Review of Univensity Expulsions, 72 YALE L.J. 1362, 1377-79 (1963). Nevertheless one commentator has described "the theory that there exists an implied contract between the student and the institution" as "[t]he most enduring and pervasive" of the "nany different legal doctrines" used to describe the relationship between a university and its students. Note, supra note 80, at 253.

83. Moore v. Student Affairs Comm. of Troy St. Univ., 284 F. Supp. 725, 729 (M.D. Ala. 1968).

84. See Comment, supra note 82, at $1378-79$ (1963); cf. Note, supra note 80 , at 265.

85. One coinunentator has pointed out the existence of substantial divergences between contract law as applied to commercial transactions and contract law as applied to the implied contract between student and university. See Note, supra note 80 , at 262-63. 
ship noncontractual if a party brought suit under the contract for damages or specific performance.

But even in a state whose courts are still wholly favorable to the contract theory, it may be questionable whether the sale of a term paper to a student is conduct which tortiously interferes with the academic "contract." The "assembling of information in such a way that the party persuaded recognizes it as a reason for breaking the contract," $"$ in essence what a term paper company does when it prepares or sells a term paper, may not be sufficient interference to constitute liability. More importantly, it is unclear whether the school contract is enforceable in any sense by either party. Although the student does subject himself to university sanctions, the university cannot require specific performance, nor could an institution bring an action for damages under the contract. In this regard, courts have split over whether or not a contract unenforceable as between the parties to it will support an action for tortious interference with a contract. ${ }^{87}$

Thus, actions to enjom and thereby to impose prior restraints on term paper company activities on a theory of tortious interference will fail independently of first amendment claims in states which (1) do not recognize the contract theory of student-university relationships, (2) will not permit action for tortious interference on an unenforceable contract and which might hold a student-university contract unenforceable in certain contexts, or (3) do not recognize terin paper sales as a significant interference with the academic contract.

\section{Indirect Attacks on Corporate Status}

Sanctions other than injunctions, such as harrassing attacks upon the corporate status of term paper companies, also merit prior restraint scrutiny. Quo warranto proceedings, ${ }^{88}$ for example, have been utilized to bring about the ultimate dissolution of "undesirable" busi-

86. W. Prosser, HANDBOoK of the LaW of TORTS 535 (4th ed. 1971).

87. See 84 A.L.R. 43 (1933); 26 A.L.R.2d 1227 (1952). Compare Ely v. Donoho, 45 F. Supp. 27 (S.D.N.Y. 1942) (contract must be legal and enforceable before an action can be brought against a third person for procuring its breach) with Louis Kamm, Inc. v. Fink, 113 N.J.L. 582, 175 A. 62 (Ct. Err. \& App. 1934) (liability of one wrongfully procuring another to breach a contract is not affected by fact that contract is void for noncompliance with statute of frauds).

88. Historically, there was a distinction between quo warranto, a writ to question "by what authority" a putative corporation assumes to act-and scire facias, requiring a legally existing body "to show cause" why its corporate franchise slould not be forfeited. Currently both types of review are commingled under a single label ("quo warranto"). 2 G. HORNSTRIN, CoRporATION AND LAW PRACTICE $\$ 813$, at 355-56 (1959). 
nesses. ${ }^{89}$ In State $v$. Saksniit, ${ }^{90}$ an irate New York court not only ordered dissolution, but ordered the term paper magnates to pay restitution damages equivalent to the amount of gross revenues received over the entire span of the company's alleged existence. Future dissolution actions might proceed under statutory provisions forbidding (1) the exercise of corporate powers not granted to a corporation by law or otherwise, and (2) the general abuse and misuse of corporate powers. ${ }^{91}$

The continued success of this apparent discriminatory enforcement depends upon the likelihood of first amendment intervention. Because prohibitions aimed at specific term paper company activities, such as "preparation" or "sale," involve obvious direct prior restraints on arguably protectable conduct, it would seem to follow that the selective enforcement of valid corporation statutes for the purpose of driving the term paper distributor out of business altogether should also be suspect.

\section{Prohibitions Against Common Law and Statutory Fraud}

A final major source of potential prior restraint on the activities of term paper companies is governmental action based on the federal civil nuail fraud statute as well as on grounds of common law fraud.

89. In Connecticut, an action initiated against an incorporated term paper company sought, inter alia, a writ of quo warranto to dissolve the corporation. Before the case could be tried, the defendant corporation was voluntarily dissolved, and its harrassed president left the state. Letter from Bernard F. McGovern, Jr., Assistant Attorney General, State of Connecticut, to Institute of Government, Chapel Hill, North Carolina, Feb. 1, 1973. The Attorney General of Michigan has also instituted suit against Write-On, Inc., under a similar theory. Despite the company's apparent willingness to curtail its term paper sales, the court granted a temporary injunction. Letter from Byron H. Higgins, University Attorney, Wayne State University, to Institute of Government, Chapel Hill, North Carolina, Apr. 3, 1973; Kelley v. Write-On, Inc., No. 7476 (Cir. Ct., Washtenaw County, Mich., May 3, 1972).

90. 69 Misc. $2 d 554,332$ N.Y.S.2d 343 (Sup. Ct. 1972).

91. Complaint of State of New York at 8, State v. Saksniit, 69 Misc. 2d 554, 332 N.Y.S.2d 343 (Sup. Ct. 1972). N.Y. Bus. CoRP. LAW $\$ 1101$ (McKinney 1963) provides, in pertinent part:

(a) The attorney-general may bring an action for the dissolution of a corporation upon one or more of the following grounds:

(i) That the corporation has exceeded the authority conferred upon it by law, or has violated any provision of law whereby it has forfeited its charter, or carried on, conducted or transacted its business in a persistently fraudulent or illegal manner, or by the abuse of its powers contrary to the public policy of the state has become liable to be dissolved.

Term paper companies might be especially vulnerable to statutes requiring the identification of the principals involved in a corporation or unincorporated association. See, e.g., Mass. ANN. Laws ch. 110, $\$ 5$ (Supp. 1966). 
Although a mail-stop order under the federal civil mail fraud statute ${ }^{22}$ does not affect outgoing mail of the allegedly fraudulent enterprise, it does require an inspection in the presence of postal officials of all incoming first-class mail. ${ }^{93}$ First-class inail found to be unrelated to the "unlawful activity" carried on by the company would be delivered following the joint inspection of the inail by the intended recipient and the postal service, but mail found to be related would be "appropriately marked" and returned to its sender.

The application of the federal civil mail fraud statute to the term paper coinpanies nay be questionable in several respects. Since a mailstop order would cripple mail order businesses, as well as larger term paper enterprises sucli as Write-On ${ }^{94}$ or Ward Warren Manuscripts, ${ }^{95}$ the advance intervention of inspections and government officials arguably places a prior restraint on the exercise of first amendment rights. ${ }^{96}$

92. 39 U.S.C. $\& 3005$ (1970) provides, in pertinent part:

(a) Upon evidence satisfactory to the Postal Service that any person is engaged in conducting a scheme or device for obtaining inoney or property through the mail by means of false representations, ... the Postal Service may issue an order which-

(1) directs the postmaster of the post office at which mail arrives, addressed to such a person or to his representative, to return such mail to the sender appropriately marked as in violation of this section, if the person, or his representative, is first notified and given reasonable opportunity to be present ....

93. Some term paper companies are known to have been so organized that inanagers of branch offices telephoned orders to the parent company at specified times daily:

Please place all of your orders, daily, by telephone. This will be done at a

predetermined time which will be forwarded. No mail orders will be accepted.

This will lead to expediency and efficiency; and the end result will be a

larger profit margin for your company. Exhibit 10 to Complaint of State of

Wisconsin at 5, Bruce Inksetter, No. 997 (Wis. Dep't of Agriculture, May 16, 1972). Papers, paid for in advance by the student at the branch office of this company, were then sent directly by the parent company to the purchasing student through the mail. Such activity by term paper companies would be in no way restricted by a mail-stop order, though an effective mail-stop order might preclude branch officers from transmitting payments to the parent company.

94. See notes 16-17 supra and accompanying text. The unost complete account of Write-On's activities is contained in Stemway \& Karle 8.

95. See notes 18-19 supra.

96. If such mail-stop orders were to be sought and obtained nationally against both parent companies and branch offices, as they clearly might be under the argument that branch offices are "representatives" of the parent company, 39 U.S.C. $\$ 3005$ (b), (c) (1970), it would be impossible for the parent company to communicate with the managers of its branch offices except by telephone or direct conversation in person or possibly through messages transimitted in packages sent as private freight by truck or airplane. No mail could be sent either by the parent company to a branch manager, or by a branch manager to the parent company without being intercepted and returned. Companies less complexly structured than Write-On and Ward Warren Manuscripts frequently depend for much of their business on direct mail-orders from stu- 
Not only may stop orders be prior restraints, but the breadth with which the statute has formerly been applied may not hold up under careful scrutiny. In United States v. International Term Papers, Inc. ${ }^{97}$ an action against four Boston companies to detain incoming mail pending statutory administrative proceedings, the First Circuit held that since section 3005 of the federal statute specified "neither the timing, the source, nor the target of the false representation," it should be given "as broad an interpretation as the language can gracefully bear."98 The government successfully argued that the requisite fraud need not be "directly related to obtaining money through the mails"; nor did the statute "require either that the victim of the false represenations send or receive mail related to the scheme or that the false representations be made by mail." 99 Under this construction of section 3005, the federal civil mail fraud statute covers schemes, such as term paper arrangements, "in which the party receiving inoney through the mails effectuates his scheme by means of a second party's [the student's] false representations to a third party [the professor]." 100

The First Circuit thus read the statute broadly to include all potential victims, regardless of whether the mails are used to defraud directly or indirectly. It sliould be noted, however, that, unlike section

dents. These companies would be prevented from receiving any such orders, and would be forced to sell only to local students able to give an order in person and subsequently pick up a completed paper in person. The scope of operations of even "local" companies would be drastically limited by a mail-stop order. Companies selling only term papers would perhaps be unable to receive statements from their banks or bills from utility companies, if any payments for purchased term papers were received by mail or any term papers were sent through the mails to purchasers; companies not so using the mails would arguably be immune from mail-stop orders. But see Donaldson v. Read Magazine, 333 U.S. 178 (1948). Possibly to the extent that the activities of term paper companies are constitutionally protected, a mail-stop order would be constitutionally impermissible as directed to them, though permissible as directed to other companies not engaged in constitutionally protected activities.

97. 477 F.2d 1277 (1st Cir. 1973), vacating and remanding 351 F. Supp. 76 (D. Mass. 1972).

98. $477 \mathrm{~F} .2 \mathrm{~d}$ at 1279.

99. Brief of the United States at 15, United States v. International Term Papers, Inc., 477 F.2d 1277 (1st Cir. 1973). The First Circuit now agrees with this position:

Nor is the language of $\$ 3005$ limited to one wlio falsifies to another and subsequently receives noney. Unlike the language im similar statutes aimed at preventing the use of the mails for fraudulent purposes, neither the timing, the source, nor the target of the false representation is here specified. $477 \mathrm{~F} .2 \mathrm{~d}$ at 1279.

100. Brief of the United States at 16, United States v. International Term Papers, Inc., 477 F.2d 1277 (1st Cir. 1973) (einphasis added). It might be more accurate to state that a term paper service is a scheme in which a party receiving money through the nails does so for assisting a second party (the student) in his (the second party's) making false representations to a third party (the professor), which seems to make the court's readimg of the statute even niore strained. 
3005, both section 17(a) of the Securities Act of $1933^{101}$ and section 206 of the Investment Advisers Act, ${ }^{102}$ to which the government analogized the civil mail fraud statute, contain the phrase "or indirectly." Despite the conspicuous absence of similar wording, which should logically restrict the civil mail fraud statute on its face to the direct use of the mails to defraud, the First Circuit's broad interpretation has implicitly added "directly or indirectly" to section 3005 .

Although the civil mail fraud statute was held to be consitutional in Donaldson v. Read Magazine, ${ }^{103}$ the Donaldson case may not be determinative as to constitutional challenges by term paper companies. First, the busimess contesting a 1nail-stop order in Donaldson obtained money directly from the persons on whom the fraud was being practiced. ${ }^{104}$ The purchase of a term paper by itself defrauds neither party to the transaction. Second, first amendment issues were found not to exist in Donaldson. ${ }^{105}$ Third, the business found to be guilty of using the mails to defraud was also engaged in "legitimate" business operations and its challenged activity was only a sinall portion of its total business activities. ${ }^{106}$ Thus, the mail inspections involved little more than a general nuisance to the business, whereas a mail-stop order might substantially hinder a term paper operation. Fourth, the approved mail-stop order was carefully limited to first-party addresses so as to be minimally restrictive, thereby evincing a judicial intent to confine the application of section 3005. ${ }^{107}$

101. 15 U.S.C. $\$ 77 q(a)(1970)$. That section provides:

It shall be unlawful for any person in the offer or sale of any securities ... directly or indirectly

(1) to employ any device, scheme, or artifice to defraud, or

(2) to obtain money or property by means of any untrue statement of a inaterial fact or any omission to state a material fact necessary in order to make the statements made, in the light of the circumstances under which they were made, not misleading, or

(3) to engage in any transaction, practice, or course of business which operates or would operate as a fraud or deceit upon the purchaser. Id. (Emphasis added.)

102. 15 U.S.C. $\S 806-6(1970)$. That section unakes it unlawful for "any investmeut adviser, by use of the mails or any means or instrumentality of interstate counmerce, directly or indirectly . . . to employ any device, scheme, or artifice to defraud any client or prospective client." (Emphasis added). Id. But the group of specicified victims, which the government argues is a limited group of victims, is actually a group which includes all potential victims of fraudulent schemes of investment advisers.

103. 333 U.S. 178, 189-92 (1948).

104. Id. at 180 .

105. Id. at 191.

106. Id. at 181-82.

107. Id. at 183. But, as the district court in International Term Papers was careful to point out, the federal criminal mail statute "prohibits inailing intended to induce a fraud against third parties even where the recipient of the inailing is in no way fooled or defrauded." 351 F. Supp. at 79 n.9. In Alexander v. United States, 95 F.2d 873 
In addition to statutory fraud prohibitions, courts have also permitted prior restraints upon term paper companies based upon common law fraud principles. Though the first annendment clearly permits subsequent punishment for fraudulent conduct which has previously occurred, ${ }^{108}$ it does not necessarily permit injunctive prior restraints against possibly fraudulent future conduct. ${ }^{100}$ In this regard, since term paper companies do not, despite emotional and moral arguments, ${ }^{110}$ defraud their student and nonstudent customers, full first ainendment protection should arguably be accorded to activity unquestionably protectable but for the mere possibility of fraud upon a third party. However, in enjoining fraudulent conduct, the courts have generally ignored the first amendment argument. ${ }^{111}$

(8th Cir), cert. denied, 305 U.S. 637 (1938), "a scheme that [bore] more than a passing resemblance" to the preparation and sale of term papers to students intending to plagiarize was involved. - Brief for the United States at 23, United States v. International Term Papers, Inc., 477 F.2d 1277 (1st Cir. 1973). In Alexander fraudulent medical and chiropractic diplomas, certificates, and licenses were prepared for imposters who defrauded the public by posing as doctors and chiropractors. The Eighth Circuit upheld a conviction under the federal criminal mail fraud statute, then 18 U.S.C.A. $\$ 338$. But in Alexander there was no conduct arguably entitled to first amendment protections. Thus it would be difficult to argue that term papers may be analogized to the fraudulent documents involved in Alexander. Also, in Alexander the fraudulent documents were themselves untruthful, whereas in the case of a term paper only the name under which the paper is submitted is false evidence of the authorship of a paper whose content is likely to be truthful. Finally, in Alexander there was arguably a compelling state interest, despite the absence of any curtailinent of first amendment freedoms, which would be absent in a term paper case: a state's strong interest in the health of its residents. Furthermore inasmuch as receipt of a diploina depends upon many factors other than completion of term papers, submission of a plagiarized term paper is much less directly related to any possible fraud on the public, and to the extent that the public is less likely to rely on an ordinary diploma than on a doctor's or chiropractor's certificate as a guaranty of competence, such conduct entails a lower probability of any public fraud.

108. See note 12 supra.

109. "[T] he Commission's order appears to be in effect an outstanding injunction against certain publications-the essence of a prior restraint." Pittsburgh Press Co. v. Pittsburgh Comm'n on Human Relations, 413 U.S. 376, 395 (1973) (Burger, C.J., dissenting).

110. The fraud initially is upon the student. He is the one who is being victimized or exploited by this subtle and innocent-looking scheine. The term paper salesman takes unfair advantage of the student who may be under pressure and possibly falling behind in course requirements, by showing him an easy way out in return for the payment of money .... He is offered a ready-made product in innocent-looking form, stamped for research and reference purposes only, to enhance its dignity. It takes unfair advantage of the student's moral weakness and his willingness to compromise honesty with expediency. The student loses in two ways: first, in terms of compromise with morality and, second, in the depreciated value or quality of his own education. Bruce Inksetter, No. 997, at 7 (Wis. Dep't of Agriculture, May 16, 1972).

111. But see Motion, Memorandum and Proof of Service of Gerald S. Lobosco at 1-2, Board of Trustees of the Ohio St. Univ. v. Term Papers Unlinited, No. 72CV- 
In sum, at least six of the principal responses developed by the courts and legislatures to deal with the plagiarism problem are fraught with first amendment difficulty. But because a prior restraint only carries a presumption of unconstitutionality to be balanced against state interests, it becomes necessary to determine whether the state policies vindicated by these restraints are sufficiently "compelling" to justify their imposition.

\section{The Unconstitutionality of Prior Restraints on TERM PAPER COMPANY OPERATIONS}

The Supreme Court's hostility to prior restraints ${ }^{112}$ on freedoms protected by the first amendment was definitively expressed in Near $v$. Minnesota, ${ }^{113}$ a case striking down a statutory prior restraimt which prevented newspapers from publishing "malicious, scandalous and defamatory" articles. ${ }^{114}$ Holding the Minnesota statute unconstitutional as applied, the Court in Near indicated that its hostile attitude toward prior restraints might be overcome only under "exceptional" circumstances: ${ }^{115}$

The objection has also been made that the principle as to immunity from previous restraint is stated too broadly, if every such restraint is deemed to be prohibited. That is undoubtedly true; the protection even as to previous restraint is not absolutely unlimited. But the limitation has been recognized only in exceptional cases . . . . No one would question but that a government might prevent actual obstruction to its recruiting service or the publication of the sailing dates of transports or the number and location of troops. On similar grounds, the primary requirements of decency may be enforced against obscene publications. The security of the commumity life may be protected against incite-

03-1010 (C.P., Franklin County, Ohio, filed May 16, 1972); Motion, Memorandum, Notice and Proof of Service of Gerald S. Lobosco at 3-10, id.; Memorandum Contra Motion to Vacate, Terminate or Dissolve Temporary Restraining Order for Board of Trustees at 1-6, id.

112. "The special vice of a prior restraint is that communication will be suppressed, either directly or by inducing excessive caution in the speaker, before an adequate determination that it is unprotected by the First Amendinent." Pittsburgh Press Co. v. Pittsburgh Comm'n on Human Relations, 413 U.S. 376, 390 (1973). See generally T. EMERson, The System of FreedoM of Expression, 503-12 (1970); Emerson, The Doctrine of Prior Restraint, 20 LaW \& CONTEMP. Prob. 648 (1955).

113. 283 U.S. 697 (1931).

114. Id. at 702 .

115. According to a leading authority on the first amendment, "the reasons for making these exceptions are unclear... and the whole matter remains obscure.... [T] he Court never undertook to explain the functional basis of the prior restraint doctrine." T. EMERSON, THE SYSTEM, supra note 112, at 506. 
ments to acts of violence and the overthrow by force of orderly government. ${ }^{116}$

Prior restraints upon term papers clearly fall outside these delineated exceptions. ${ }^{117}$

Chief Justice Hughes forewarned in Near itself that future courts might create new Near exceptions "according to the principles governing the exercise of the jurisdiction of courts of equity."118 Although subsequently Chief Justice Burger has similarly recognized that unforeseen future events might compel another categorical infringement of first anendment rights, ${ }^{119}$ it is doubtful that a new exception will be developed to allow prior restraints of terun paper company activities. The Court has im fact recently restricted the "obscenity" and "national security" exceptions to the prohibition against prior restraints. ${ }^{120}$ In five recent cases, ${ }^{121}$ the Court seemingly ignored the Near mandate to

116. 283 U.S. at 715-16. Most recently Chief Justice Burger, dissenting in New York Tiunes Co. v. United States, 403 U.S. 713 (1971), stated,

So clear are the constitutional limitations on prior restraint against expression, that from the time of Near v. Minnesota . . . we have had little occasion to be concerned with cases involving prior restraints against news reporting on matters of public interest. There is therefore little variation among the mennbers of the Court in terms of resistance to prior restraints against publication. Id. at 748 .

The majority's per curiam opinion quoted from Bantam Books, Inc. v. Sullivan, 372 U.S. 58 (1963), to the effect that "[a]ny system of prior restraints of expression comes to this Court bearing a heavy presunption against its constitutional validity." 403 U.S. at 714, quoting 372 U.S. at 70 . See also Organization for a Better Austin v. Keefe, 402 U.S. 415 (1971).

117. Furthermore, term papers cannot be reached by the Court's opinion in Ginzburg v. United States, 383 U.S. 463 (1966), which held that in doubtful cases evidence of pandering might be used to complete the test for obscenity established in Roth v. United States, 354 U.S. 376 (1957). Though it may be argued that term paper coinpanies "pander" to the weaknesses of students by offering their services, unless those services consist of the production of obscenity, such arguable pandering may not be considered by a court. The temptations held out to prospective student purchasers by term paper companies are probably constitutionally indistinguishable from the blandishments of a seller of crossword puzzles or the publisher of cookbooks.

118. 283 U.S. at 716.

119. "There are no doubt other exceptions no one has had occasion to describe or discuss." New York Times Co. v. United States, 403 U.S. 713, 749 (1971) (Burger, C.J., dissenting). The Court inay have given tacit recognition to such a possibility in Cohen v. Califormia, 403 U.S. 15 (1971), when it stated that "most situations where the State has a justifiable interest in regulating speech will fall within one or nore of the various established exceptions. . ." (emphasis added). Id. at 24.

120. In Pittsburgh Press Co. v. Pittsburgh Comm'n on Human Relations, the Court alluded to "the narrowness of the recognized exceptions to the principle that the press may not be regulated by the Governuent," and stated that "[o]ur inquiry must therefore be whether the challenged order falls within any of these exceptions" (emphasis added). 413 U.S. 376, 382 (1973). See also Cohen v. Califorma, 403 U.S. 15, 24 (1971).

121. Papish v. Board of Curators of the Univ. of Mo., 410 U.S. 667 (1973); Rosen- 
enforce the "primary requirements of decency" against "obscene publications," and instead severely limited the government's power to control formerly unprintable or unspeakable expressions of opinion. ${ }^{122}$ In New York Times Co. v. United States, ${ }^{123}$ the government vainly attempted to show a constitutionally sufficient necessity for maintaining the secrecy of the "Pentagon Papers." The Court's holding indicated that a prior restraint in the form of a suit to enjoin publication could not be validated as an indispensable element of "the security of the community life" or as coming within the "[national] security" Near exception. ${ }^{124}$ That no new exceptions to the Near doctrine will be forthcoming is further evidenced by the Supreine Court's disinclination to develop an exception previously in an analogous context. In the 1950's, when the debate over crime comic books approached the imtensity of the current concern over term paper companies, ${ }^{125}$ a new exception to the prohibition against prior restraints which would expressly cover crime comics was unsuccessfully urged as one solution to the problem. ${ }^{120}$

feld v. New Jersey, 408 U.S. 901 (1972); Kois v. Wisconsin, 408 U.S. 229 (1972); Gooding v. Wilson, 405 U.S. 518 (1972); Cohen v. California, 403 U.S. 15 (1971).

122. See text accompanying note 116 supra.

123. 403 U.S. 713 (1971).

124. A "national security" exception may perhaps be found in the two Near phrases "prevent actual obstruction to its recruiting service" and "publication of the sailing dates of transports or the number and location of troops." 283 U.S. at 716. The contours of the "national security" exception are not entirely certain. The result in New York Times Co. is relied upon by defendants in Motion, Memorandum, Notice and Proof of Service of Gerald S. Lobosco, Board of Trustees of the Ohio St. Univ. v. Term Papers Unlimited, No. 72CV-03-1010 (C.P., Franklin County, Ohio, filed May 16, 1972). Defendants in that case argued that if "Freedom of Expression" could not be restrained because of "National Security" in New York Times Co., then equally "Freedoin of Expression" should not be restrained because of a merely "Burdensome Task," the problem faced by agents of plaintiffs in "ferreting out" evidence of plagiarism by students who had purchased term papers from defendants. Motion, Memorandum, Notice and Proof of Service of Gerald S. Lobosco, at 9, Board of Trustees of the Ohio St. Univ. v. Term Papers Unlimited, No. 72CV-03-1010 (C.P., Franklin County, Ohio, filed May 16, 1972).

125. See Winters v. New York, 333 U.S. 507 (1948); Katzev v. County of Los Angeles, 52 Cal. 2d 360, 341 P.2d 310 (1959); Police Comn'r v. Siegel Euterprises, Inc., 223 Md. 110, 162 A.2d 727, cert. denied, 364 U.S. 909 (1960); Adams v. Hinkle, 21 Wash. 2d 763, 322 P.2d 844 (1958). See generally Duesenberg, Crime Comic Books: Government Control and Their Impact on Juvenile Conduct, 7 MERCER L. Rev. 331 (1956); Note, Regulation of Comic Books, 68 HARv. L. Rev. 489 (1955); Comment, Delinquency, Comic Books and the Law, 18 OHIo ST. L.J. 512 (1957); Note, Crime Comics and the Constitution, 7 Sran. L. Rev. 237 (1955).

126. "The growth of the comic-book industry has been thought by some to raise new problems that demand for their solution some form of prior restramt." Emerson, The Doctrine, supra note 112, at 662 . One commentator suggested that "[p]erhaps 
Though the activities of term paper companies do not arouse imdignation and fear comparable to the Near Court's concern with obscene publications and imcitements to the forceful overthrow of orderly government, ${ }^{127}$ the threat to certain state interests may nevertheless require a balancing test ${ }^{128}$ to determine the degree of protection to be given to the exercise of first amendment rights in this area. ${ }^{129}$ In $N A A C P$ $v$. Button, ${ }^{130}$ a case involving an atteinpt by Virginia to restrict the actvities of NAACP attorneys in that state, the Court stated that "only a compelling state interest in the regulation of the subject within a State's constitutional power to regulate can justify limiting First Amendment freedoms." ${ }^{31}$ Similarly, Justice Brennan, concurring in Lamont v. Postmaster General, ${ }^{132}$ relied lieavily on Button for the proposition that the state's interest in protecting its citizens from the vagaries of Communist propaganda was not "compelling" enough to justify a statutory prior restraint on first amendment rights. Necessarily implying that the right to receive and the right to distribute information were correlative

crime comics constitute a unique category of unprotected expression" (emphasis added). Note, Crime Comics, supra note 125, at 242. Another commentator, after considering the prior restraint question, similarly declared "that a statute imposing a prior restraint but drafted in light of the special features of the comic book medium would be more likely to satisfy constitutional requirements." Note, Regulation of Comic Books, supra note 125, at 492. Yet another commentator, after analyzing the judicial attitude toward prior restraint, expressed the traditional view that "it is highly doubtful that any further exceptions would be created to embrace the crime comic book problem." Duesenberg, supra note 125, at 343.

127. See text accompanying notes $112-17$ supra.

128. "So long as Mernbers of this Court view the First Amendment as no more than a set of 'values' to be balanced against other 'values,' that Amendment will remain in grave jeopardy." Pittsburgh Press Co. v. Pittsburgh Comm'n on Human Relations, 413 U.S. 376, 402 (1973) (Stewart, J., dissenting). Nonethless the majority opinion in Pittsburgh Press clearly contemplates that some use may be made of a balancing test in the first amendment area:

Any First Amendment interest which might be served by advertising an ordi-

nary commercial proposal and which might arguably outweigh the govern-

mental interest supporting the regulation is altogether absent when the com-

mercial activity itself is illegal and the restriction on advertising is incidental

to a valid limitation on economic activity (emphasis added). Id. at 389.

Pittsburgh Press, however, has dangerous implications, for a balancing test necessarily involves "a great temptation to reduce a constitutional right to the same weight as every other interest . . ." Brandywine-Main Line Radio, Inc. v. FCC, 473 F.2d 16, 65 n.7 (D.C. Cir. 1972) (Bazelon, J., dissenting), cert. denied, 412 U.S. 922 (1973).

129. Beginning over a third of a century ago in Gitlow [the prior decisions of this Court] have consistently reserved for future decision possible situations in which the claimed First Amendment privilege might have to give way to the necessities of the public welfare. Times Film Corp. v. City of Chicago, 365 U.S. 43, 47 (1961).

130. 371 U.S. 415 (1963).

131. Id. at 438 .

132. 381 U.S. 301 (1965). 
rights, ${ }^{133}$ the Court in Lamont voided a federal statute directing the Postmaster General to withhold foreign Communist propaganda pending a delivery request from the addressee.

Notwithstanding the fact that in Lamont the state interest in restricting propaganda dissemination did not constitutionally outweigh the accoinpanying infringeinents on first amendınent rights, ${ }^{134}$ valid state interests might argnably prevail in the term paper context. Thus, in some term paper cases, the plaintiffs have broadly claimed that the necessity of protecting term paper coinpany activities should be counterbalanced by strong "public policy" considerations. The board of trustees of the Ohio State University, in filing to enjoin temporarily a Columbus term paper company, complained of "the disruptive effects outfits profiting from facilitating plagiarism have had in the processes of education at the college level."135 The trustees of Boston University have likewise sought a "binding declaration" that the activity of Boston-area term paper companies violated public and educational policy in part because the integrity and intrinsic value of academic degrees is a matter of public policy and public concern. ${ }^{136}$ The im-

133. Id. at 305.

134. No compelling state interest was found in Sherbert v. Verner, 374 U.S. 398 (1963), as the Court narrowly construed "sufficiently coinpelling state interest." " 'Only the gravest abuses, endangering paramount interests, give occasion for permissible limitation." " 374 U.S: at 406, quoting from Thomas v. Collins, 323 U.S. 516, 530 (1945). On the other hand, in United States v. O'Brien, 391 U.S. 367 (1968), a conviction for knowing destruction of a draft card was upheld because a "sufficiently important governmental interest," an interest "compelling; substantial; subordinating; paramount; cogent; strong" was found to exist and, unore importantly, speech and non-speech elements were "combined in the same course of conduct." Id. at 376-77. O'Brien has been criticized as "a serious setback for First Amendinent theory." T. EMERson, The System, supra note 112, at 83 (1970). Judge J. Skelly Wright, in his dissent to Capital Broadcasting Co. v. Mitchell, 333 F. Supp. 582 (D.D.C. 1971), has argued that the clear and present danger test should be applied only to a "confined" area of cases:

Where otherwise protected speech can be shown to present a "clear and present danger" of a severe evil which the state has a right to prevent, suppression of that speech has on occasion been permitted.... While it cannot be denied that public health is .... a vital area of state concern, it is different frown the state interest in security in one crucial respect. Whereas there are always innocent victims in riots and revolutions, the only person directly harmed by smoking cigarettes is the person who decides to smoke them. The state can stop speech in order to protect the innocent bystander, but it cannot impose silence inerely because it fears that people will be convinced by what they hear and thereby harm theinselves. Id. at 593.

135. Memorandum in Support of Motion for Teinporary Injunction of Board of Trustees at 6, Board of Trustees of the Ohio St. Univ. v. Term Papers Unlimited, No. 72CV-03-1010 (C.P., Franklin County, Ohio, filed May 16, 1972).

136. Bill for Declaratory Judgment of Trustees of Boston University at 7, 8, 3, Trustees of Boston Univ. v. Champion Research Corp., Equity No. 96114 (Super. Ct., Suffolk County, Mass. 1972). 
portance of the integrity of academic degrees may best be illustrated by the remarks of one recent commentator:

Perhaps crude justice of sorts will have been done on the day when some termpaper executive looks up from his hospital operating table to see one of his most loyal customers approaching in surgeon's gown, scalpel and sutures at the ready. ${ }^{137}$

Through Chief Justice Burger, the Supreme Court has called for a degree of public protection which would in certain contexts abrogate first amendment protection. ${ }^{138}$ "To protect the weak, the uninformed, the unsuspecting, and the gullible from the exercise of their own volition," 139 first amendment compromise may be necessary. In the same spirit, a New York court recently upheld the state statute forbidding the fraudulent obtaining of an academic degree ${ }^{140}$ because, as

137. Change, supra note 15 , at 47 . There have been no suggestions yet that lawyers and doctors and other professionals are coasting through their professional training with purchased term papers. It is misleading to encourage irrational fears of the possible consequences of a horde of unqualified baccalaureates. Apart from the public expectation that a college diploma be indicative of disciplined application to the attainment of academic excelleuce and perhaps valuable mental and moral disciplines, if not measurable achieveinent of these ends, there is little to distinguish the culpability of the vendor of term papers from that of the bookseller who advertises his products as able to confer a false aura of culture, education, or distinction. But no one would beheve the purchaser of such books guilty of any fraudulent misrepresentation in attempting to pass himself off to his acquaintances as more literate or tasteful than he really is, nor would anyone seek to hold the seller of such "status" books liable for fraud, though he clearly knew the intended use of the books sold by him and may, in fact, have suggested such use. Thus, the fraud committed on the public-at-large by purchases of term papers may not be as serious as it initially appears, if it is hardly distinguishable from the permissible misrepresentation of the culturally insecure. Justifiable legislative fears that unqualified persons may be admitted to or enter upon the practice of a learned profession such as law or medicine should probably not be extended to cover possible misrepresentations by every undeserving possessor of a college diploma.

138. Paris Adult Theatre I v. Slaton, 93 S. Ct. 2628 (June 21, 1973).

139. Id. at 2638-39. But, in an earlier case, invalidating an overbroad ordinance requiring identification of the issuers of handbills, the Court was careful to avoid any decision on the relationship between first amendment protections and narrowly drawn statutes designed to prevent fraud:

Counsel has urged that this ordinance is auned at providing a way to identify those responsible for fraud, false advertising and libel. Yet the ordinance is in no manner so limited, nor have we been referred to any legislative history indicating such a purpose. Therefore we do not pass on the validity of an ordinance limited to prevent these or any other supposed evils. Talley v. California, 362 U.S. 60, 64 (1960).

140. N.Y. EDuc. LAW $\S 224$ (McKinney 1969) provides, in pertinent part:

(2) No person shall buy, sell or fraudulently or illegally make or alter, give, issue or obtain or attempt to obtain by fraudulent means any diploma, ..

(4) ... [A]ny other violation of this section sliall be a misdemeanor; and any person who aids or abets another, or advertises or offers limself to violate the provisions of this section, shall be liable to the same penalties. 
James Madison wrote, "[e]ducation . . . is the true foundation of civil liberty." Consequently, the "[a]ssisting and promoting [of] plagiarism .... strikes at the core of the educational process, and thus at very lieart of a free society."141

Unless these asserted state justifications are constitutionally "compelling," the curtailment of term paper company operations in advance of communication constitutes an impermissible prior restraint. A state's public policy simply becomes irrelevant if its enforcement is unconstitutional. Though courts may be disturbed by the prosecutorial difficulties inherent in attacking term paper plagiarism, ${ }^{142}$ increased ease of prosecution is not a compelling state interest that can overcome applicable first amendment protections. ${ }^{143}$ In this regard, it is by no means conclusive that discouragement of term paper companies is necessary in order to effect the encouragement of "schools and the means of education."144 Thus, given the difficulty of justifying the maintenance of prior restraints on term paper entrepreneurs, the aforementioned sanctions against them appear to have been founded more on public outrage than on studied legal precedent. ${ }^{145}$

This statute has not been authoritatively construed by the New York courts. Intended primarily, it would seem, to apply to professional and graduate degrees, it probably does not cover the case of the high school student who submits a plagiarized book report and later graduates from high school. Accordingly, reliance on this statute must remain suspect nntil the statute has been construed by the New York Court of Appeals.

141. State v. Saksniit, 69 Misc. 2d 554, 332 N.Y.S.2d 343; 349 (Sup. Ct., 1972). It therefore follows from such dramatically emotional logic that "[t] $]$ he busimess defendants are conducting is morally wrong" and "is directly opposed to the declared public policy of our state." Id. at 560, 332 N.Y.S.2d at 350.

142. See note 16 supra.

143. Increased ease of prosecution is not an interest sufficient to validate a prior restraint. "A consideration based on ease-of-conviction is now totally bereft of explicit support and does not deserve the dignity of extended discussion." Levy v. Parker, 478 F.2d 772, 795 (3d Cir. 1973). See also Schneider v. State, 308 U.S. 147, 164 (1939).

144. The Attorney General of Michigan, in Kelly v. Write-On, also alleged that Write-On "has subverted the process of education and learning contrary to the public policy of this State" as set forth in Article VIII, Section 1 of the Constitution of the State of Michigan. Complaint of Quo Warranto of State of Michigan at 2, Kelley v. Write-On, No. 7476 (Cir. Ct., Washtenaw County, Mich., filed Feb. 23, 1972). The pertinent provision of the Constitution of the State of Michigan reads: "Religion, morality and knowledge being necessary to good government and the happiness of mankind, schools and the means of education shall forever be encouraged." See also State v. Berson, 266 A.2d 175 (N.J. 1970): "The interest of the State in maintaining an educational system is a compelling one. Order is necessary to accomplish this, and the First Amendment cannot be used as a device to defeat such necessity."

145. Such a failure may contradict expressed judicial concern: "The 'public interest;' the standard under whicls the FCC operates, cannot be divorced from our con- 


\section{Governmental Reactions as Subsequent Punishment}

For states which feel the need for express statutory prohibition of the conduct of either the seller or the purchaser of term papers, some alternatives exist which do not evoke a prior restraint analysis-the criminalization of term paper sales and the criminalization of plagiarism itself.

\section{The Criminalization of Term Paper Sales}

In Connecticut and New York anyone guilty of conduct prohibited by the state's term paper statute has committed a class B misdemeanor. ${ }^{140}$ "Criminal simulation" and other related criminal term paper conduct may be punishable in some jurisdictions by a fine of up to $\$ 1,000$ and a sentence not to exceed six months. ${ }^{147}$ But because the Supreme Court in Schneider v. State ${ }^{148}$ voided several clearly analogous statutes, the criminalization of such protected activity warrants close scrutiny.

In Schneider, the Court struck down four statutes forbidding the distribution of leaflets rather than the hittering of streets with distributed leaflets, a result that would arguably control in a criminal prosecution brought under a state term paper statute. The discussion in Schneider of the insufficiency of the asserted state justification ${ }^{140}$ would seem especially pertinent to the analysis of the possibility of criminalizing term paper sales rather than term paper plagiarism:

Any burden imposed upon the city authorities in cleaning and caring for the streets as an indirect consequence of such distribution results from the constitutional protection of the freedom of speech and press. This constitutional protection does not deprive a city of all power to prevent street littering. There are obvious methods of preventing littering. Amongst these is the punishment of those who actually throw papers on the streets. ${ }^{150}$

temporary understanding and interpretation of the First Amendment." BrandywineMain Line Radio, Inc. v. FCC, 473 F.2d 16, 64 (D.C. Cir. 1972) (Bazelon, J., dissenting).

146. Pub. Act 73-581 (1973 West's Conn. Legis. Serv., No. 5); N.Y. Educ. LAW $\S 213(b)$ (McKinney Supp. 1973-74).

147. MD. Ann. Code art. 77A, \& 70 (Supp. 1972). See also N.C. Gen. Stat. \$ 14-118.2 (maximum fine $\$ 500$ ).

148. 308 U.S. 147 (1939). Though "the doctrine that communications of a commercial character are not protected by the First Amendment" originates in Schneider, the doctrine is seemingly limited to advertisements and other business communication. T. EMerson, The System, supra note 112, at 415. See also Note, Freedom of Expression in a Commercial Context, 78 HARV. L. REV. 1191 (1965); notes 31-32 supra and accompanying text.

149. Id.

150. 308 U.S. at 162 . 
Just as there are "obvious methods of preventing littering," so are there "obvious methods" of preventing student plagiarism with purchased term papers. And one of the most obvious would be "the punishment of those who actually" commit the act of plagiarism. In this vein, the Supreme Court has twice suggested that fraud should be separately punished as such, in such a manner as not to inhibit first amendment freedoms. ${ }^{151}$ Only a statute directly criminalizing plagiarism itself would, as constitutionally required, "least inhibit the exercise of constitutional liberties."152 Thus, because of this more specific means of regulating student plagiarism any term paper statute which criminalizes term paper sales will be subject to attack on grounds of overbreadth. ${ }^{153}$ The probable overbreadth of the term paper statutes makes them a particularly meddlesome imtrusion into the area of protected first amendment freedoms.

A state might enact a statute criminalizing plagiarism by purchasers of term papers. ${ }^{154}$ Under such a statute, a term paper company which had sold a paper to a student charged under the stat-

151. Frauds may be denounced as offenses and pumished by law. Trespasses may similarly be forbidden. If it is said that these means are less efficient and convement than bestowal of power on police authorities to decide what information may be disseminated from house to house, and who may impart the information, the answer is that considerations of the sort do not empower a municipality to abridge freedom of speech and press. Schneider v. State, 308 U.S. 147, 164 (1939).

This Court refused [in Schneider] to uphold the four ordinances on those grounds pointing out that there were other ways to accomplish these legitimate aims without abridging freedom of speech and press. Frauds, street littering and disorderly conduct could be denounced and pnnished as offenses, the Court said. Talley v. California, 362 U.S. 60, 63 (1960).

152. "In the area of First Amendment freedoms, government has the duty to confine itself to the least intrusive regulations which are adequate for the purpose." Lamont v. Postmaster Gen., 381 U.S. 301, 310 (1965) (concurring opinion).

The First Amendment would, however, be a hollow promise if it left government free to destroy or erode its guarantees by indirect restraints so long as no law is passed that prohibits free speech, press, petition, or assembly as such. We have therefore repeatedly held that laws which actually affect the exercise of these vital rights cannot be sustaimed inerely because they were enacted for the purpose of dealing with some evil within the State's legislative conupetence, or even becanse the laws do in fact provide a helpful means of dealing with such an evil. Mine Workers v. Illinois Bar Ass'n, 389

U.S. 217, 222 (1967) (citations omitted). See Abington School Dist. v. Schemp, 374 U.S. 203, 264 n.29 (1963) (Breunan, J., concurring) ("the principle that where First Amendment freedoms are or may be affected, government must employ those means which will least inhibit the exercise of constitutional liberties.")

153. In a series of decisions this Court has held that, even thongh the government purpose be legitimate and substantial, that purpose cannot be pursued by means that broadly stifle fundamental personal liberties when the end can be more narrowly achieved. The breadth of legislative abridgment must be viewed in the light of less drastic means for achieving the same basic purpose.

Shelton v. Tucker, 364 U.S. 479, 488 (1960) (footuotes ounitted). See Grayned v. City of Rockford, 408 U.S. 104, 114-21 (1972); Note, The First Amendment Overbreadth Doctrine, 83 HARV. L. REV. 844 (1970).

154. See note 9 supra. 
ute might still be joined as a defendant on a conspiracy or aiding and abetting theory. ${ }^{155}$ That such plagiarism statutes have not been enacted is perhaps attributable to two very different unarticulated and perhaps unconsidered policy considerations. The first of these may reflect legislative cynicism, the second legislative caution. The first policy consideration may entail a legislative suspicion that the criminalization of plagiarisın would, by pressuring term paper companies to alter their operating procedures, actually make plagiarism more invisible and even more difficult to prove than it now is. ${ }^{156}$ The second policy consideration, involving a strong element of caution, may be a feeling that colleges and universities should be given maximum discretion in the disciplining of plagiarisin. Mitigating circumstances in particular cases nay be considered where discretion is broad but might have to be ignored entirely were discretion to be narrowed or eliminated.

\section{ACAdemtc Reactions to Term Paper Companies}

Arguably there will remain a need for term paper statutes and stern judicial disapproval of term paper companies and their activities until educational institutions are able both (1) to ascertain the fact of plagiarisin by ineans of purchased term papers in a significant number of cases in which it occurs, and (2) to discipline uniformly the students who are guilty of such conduct. ${ }^{157}$ Nonetheless, suggestions

155. See R. Perkins, Criminal Law 654-66 (2d ed. 1969).

156. The passage of such a statute would not force term paper companies to go underground, though it might encourage them to change their modes of operation so that the names of student purchasers would never be imcluded in their business record. See note 16 supra. In many cases, business records seized from a term paper company have enabled academic officials to locate previously undetected instances of plagiarism. See Buyer Beware, Newsweer, July 3, 1972, at 49, col. 1. In Michigan, the Washtenaw County Sheriff seized a substantial portion of the files of a term paper company, and the contents of these files have been carefully studied by the office of the University Attorney at Wayne State University. Letter from Byron H. Higgins, University Attorney, Wayne State University, to Institute of Government, Chapel Hill, North Carolina, Oct. 10, 1972).

A second likely change would be to separate the catalogue (the listing by title, subject, length, and price of papers which may be purchased) and warehousing (the storage of master copies of the papers listed in a company's catalogue) functions now often performed at the same location by a term paper company. Separation of the catalogue and warehouse functions into operations performed by separate companies in different states could mean that it would be difficult to use discovery tecliniques to obtain from a term paper company known to have sold something to a particular student the master paper owned by a separate company and thought to have been sold to the student.

157. So long as disciplinary sanctions are imposed by the individual faculty member to whom the plagiarized term paper has been submitted rather than by an academic judicial body, it is unlikely that uniform sanctions can be insisted upon. 
have been made that the problems created by the appearance of term paper companies are not problems suited to or in need of either judicial or legislative resolution, but are instead problems peculiarly within the province of the academic community. ${ }^{158}$ Such an attitude seems to derive from the belief that colleges and umversities function, in part at least, as expert administrative agencies of the state with both legislative and judicial powers. ${ }^{159}$ For example, colleges and universities have been imparted the responsibility of deciding both when and how an academic degree has been obtained fraudulently. As contrasted with a university and its expertise akin to that of an administrative agency, a state court may be ill-equipped to determine whether an act of plagiarism las or las not occurred. A state court would lack both the accumulated knowledge of the possible forms which plagiarism or dishonesty might take and the accumulated experience in assessing the likelihood of plagiarism within a given academic community, ${ }^{160}$ and would perhaps lack as well the necessary skill in choosing

158. The protection of academic integrity is up to the internal process of the University through the efforts of both instructors and students. Those who ask the courts to battle Write On are attempting to take the easy route, mach as students who buy commercial term papers take the same road. Editorial, Mich. St. News (student newspaper, Michigan State University), Mar. 5, 1973 (column and page unavailable).

This attitude is supported by the difficulty in distinguishing possible forms which term paper companies might adopt from the traditional "student aid" publication, the abuse of which is currently dealt with by internal university policies. An alert term paper company threatened by a term paper statute might begin publishing and making commercially available term papers or groups of term papers in soft-bound "book" form. To solve the obvious problems of publishing and making available thousands of papers, a limited selection of "books" could be provided at each distribution point with an extensive list in the fly leaves of "other titles" available by mail.

One might also argue that the distinction might be significantly strained between such publications and "legitinate" literature. Surely, if university students nationwide began to submit Bacon's essays in freshınan writing courses, no state would attack the problein by prohibiting the publication or sale of Bacon's work, or at least no such state law would be sustained.

159. A university may establish, at any of several levels, mles defining academic dishonesty and the sanctions to be imposed on students guilty of misconduct taking the form of academic dishonesty. To do so would be to exercise a quasi-legislative function. In an individual case the university would need to determine, by means of a campus judicial body following procedures formulated and announced in advance to all students and other members of a particular acadeınic cominunity, whether an act of academic dishonesty had occurred and, if so, what sanctions should be imposed on the guilty student. To do so would be to exercise a quasi-judicial function. University actions in this regard, at least in state-supported institutions, no doubt would be subject to first amendinent review as "state actions."

160. The gravamen of plaintiff's complaints is the basic uufairness of grading systems employed by two individual professors. It is difficult to imagine an area of academic life more suitable for judicial abstention. ... [The instructor] should be given the unfettered opportunity to assess a student's performance and determine if it attains a standard of scholarship required by that 
among various available sanctions. ${ }^{101}$ In line with the approach that universities rather than legislatures or courts should solve the problems created by the term paper companies, all aspects of the academic community have begun to respond to the problems that the unexpected emergence and rapid proliferation of these companies have created.

Student newspapers have understandably been in the forefront of the term paper discussion. At least one such newspaper, which had earlier called for the enactment of term paper statutes and ordinances, has altered its position and now believes that the problem of academic plagiarisin is a problem that colleges and universities can and should handle internally. ${ }^{162}$ In addition to shifts im editorial stances, student editors of college newspapers have in some instances voluntarily decided to cease accepting advertisements froin term paper companies. ${ }^{103}$

Administrators and faculty members may be expected to adopt a sterner, inore visible, and more uniform attitude toward plagiarism than they have held in the past. ${ }^{164}$ In keeping with this more open approach, departmental policies on plagiarism are likely to be announced where in the past they may liave been only implicit, ${ }^{165}$ and

professor for a satisfactory grade. The federal judiciary should not adjudicate the soundness of a professor's grading system, nor make a factual determination of the fairness of the individual grades. Such an inquiry would necessarily entail the complete substitution of a court evaluation of a complainant's level of achievement in the subject under review, and the standard by which such achievement should be measured, for that of the professor. It would be difficult to prove by reason, logic or common sense that the federal judiciary is either competent, or more competent, to make such an assessment. Keys v. Sawyer, 353 F. Supp. 936, 939-40 (S.D. Tex. 1973). But see Comment, supra note 82, at 1394 (1963).

161. But see Private Government, supra note 82 at 1394.

162. See Editorial, Mich. St. News (student newspaper, Michigan State University), Mar. 5, 1973 (column and page unavailable).

163. See Stavisky, Term Paper "Mills," Academic Plagiarism and State Regulation, 88 Pol. ScI. Q. 445, 453 n.17 (1973). Voluntary action is required for "[t]he courts have found no rule at common law forbidding newspapers from discriminating among customers, and in the absence of a statute to the contrary they have found no authority for establishing such a rule." Note, Resolving the Free Speech-Free Press Dichotomy: Access to the Press Through Advertising, 22 U. FLA. L. REv. 293 (1969). On one campus, though, it was necessary for the Publication Board to order the protesting student newspaper to cease accepting term paper advertisements. The Chronicle (student newspaper, Duke Umiversity), Jan. 27, 1972, at 1, col. 1.

164. See Stavisky, supra note 163 , at 454.

165. A resolution passed unanimously by the Department of History at Kent State University on February 12, 1972, states:

While not doubting the honesty and imtegrity of the vast majority of K.S.U. students, the Department of History wishes to make it absolutely clear that the submission of a paper prepared in full or in part by anyone other 
where they were formerly announced orally they may now be codified and distributed in written form. ${ }^{\mathbf{1 6 6}}$ Specific university-wide rules against plagiarism $^{167}$ may be adopted on campuses which have not previously had such, and all-student or joint student-faculty judicial bodies may wish to issue policy statements setting forth their attitudes toward plagiarism. ${ }^{168}$ Despite recent academic reactions, an effective response to the term paper problem is somewhat hindered by the lack of disciplinary uniformity. Currently, considerable discretion as to the imposition of sanctions ${ }^{109}$ on a student is delegated to the mdividual

than the student who snbmits it constitutes plagiarism. In our view, plagiarism is clearly unethical and inimical to the interests of both the student involved and the academic community. Any history instructor who discovers that a student has submitted such a paper will give that student an $F$ for the course and will report his name to the dean of his college. Letter from Ken

Calkins, Assistant Professor of History, Kent State University, to Institute of Government, Chapel Hill, North Carolina, Mar. 28, 1973.

166. Harvard "prints a warning against plagiarism and the purchase of academic materials in a rules booklet given to freshmen." Chronicles of Higher Education, July 30, 1973, at 5, col. 4. The Michigan State Student Handbook, and Schedule of Courses and Academic Handbook reprints a similar admonishment. Mich. St. News (student newspaper, Michigan State University), Mar. 9, 1973, at 5, col. 2. The jurisdiction of the Student-Faculty Judiciary at Michigau State University is spelled out explicitly with respect to plagiarism:

The Judiciary shall have original jurisdiction over . . . cases involving the recommendation of an instructor and a dean for action other than, or in addition to, a failing grade in a course given on the basis of a charge of academic dishonesty. Id. at 5 , col. 1 .

167. The law that governs the prerogatives of college students and the powers of universities consists of rising tiers of authority. From ad hoc administrative and faculty rules, the layers progress upward to the supreme law of the Constitution. . . . The affirmative source of rule-making power is to be sought in articles of incorporation, charters, state delegation of legislative prerogatives, subdelegations by boards of trustees, et cetera. Van Alstyne,

The Judicial Trend Toward Student Academic Freedom, 20 U. FlA. L. Rev. 290 (1968).

168. The Student-Faculty Judiciary at Michigan State University issued a policy statement in October 1969 which read in part:

The Judiciary believes that academic dishonesty is the most serious offense that can be committed against our community. If we hear a case $\mathrm{m}$ volving academic dishonesty, and there are no mitigating circumstances, suspension is the only realistic alternative available to us. Mich St. News

(student newspaper, Michigan State Umiversity), Mar. 9, 1973, at 5, col. 2. After an editorial in the campus newspaper at Michigan State University on March 6, 1973, the Student-Faculty Jndiciary issued a comment giving statistics on the number of students tried for academic dishonesty since the issuance of the October 1969 pohicy statement, the number of students found guilty, and the number of students suspended from the university. Mitigating circumstances were said to have "in some instances affected the number of terms for which the suspension lasted." Id. at cols. 2-4. The Judiciary concluded its comment by stating: "All students should be aware that academic dishonesty can cost them nore than the price of a term paper or a failing grade for a course. It can result in suspension from the University." Id. at col. 4.

169. Options now available to or used by faculty members include:

(1) Recommendation of the student to a campus judicial board;

(2) Imposition of a failing grade in the course in which the student committed 
faculty member. ${ }^{170}$ So long as sanctions in many instances of plagiarism are imposed directly and often solely by individual faculty members, internal review before a campus judicial body will also be discretionary ${ }^{171}$ rather than mandatory for a student charged with academic dishonesty.

Academicians might also more effectively confront the term paper threat in the classrooin, where a number of teaching techniques can be utilized to deemphasize requirements amenable to plagiarism. ${ }^{172}$

the act of academic dishonesty;

(3) Requiring a student to repeat a course in a succeeding term (presumably, though not necessarily, without being registered for the course in that term);

(4) Reduction of the student's grade in the course in which the student committed the act of academic dishonesty;

(5) Agreement that because of mitigating circunstances or the overall quality of the student's work in the course aside from the act of academic dishonesty no sanction will be imposed;

(6) Reprimand;

(7) Warning. See Stavisky, supra note 163, at 445-46.

Unless a clear policy has been adopted by an individual department or by the university or college of which it is a component, other faculty members and administrators are unlikely to be aware of the options actually being used by a particular faculty meinber. Even when such a clear policy has been adopted, an individual faculty member may refuse to use one or more of his options.

170. Individual faculty members who discover that they have received purchased term papers from students may choose to deal extra-administratively and privately with the students who subinitted such papers. At the University of Wisconsin at Madison, a student purchased and turned in to his teaching assistant (TA) a paper on the movie "Virgin Spring" identical to a paper received by the same TA from a second student in another discussion section: "Instead of reporting this discovery that a purchased term paper had been submitted to the professor or to the Dean, the TA said he would give [the student] a passing grade if he would do another paper." The Daily Cardinal (student newspaper, University of Wisconsin at Madison), Feb. 1, 1972 (column and page unavailable). Even when large numbers of students are discovered by university official to be guilty of plagiarism by submitting purchased term papers to faculty members the sanctions to be enforced against the students may be determined by individual faculty members rather than by the university administration itself: "Disciplining of the 600 University of Wisconsin-Madison students who bought papers from the company has been left to the discretion of individual professors." Chronicle of Higher Education, Nov. 20,1972, at 3, col. 1. It is difficult to estimate whether sanctions decided upon by individual faculty members are lighter than sanctions decided upon by university officials would be: "A total of 162 students received failing grades and another 193 were given reduced grades in courses at the University of Wisconsin at Madison for using purchased term papers." Chronicle of Higher Education, Jan. 15, 1973, at 3, col. 1 .

171. Appearance before the Student-Faculty Judiciary is optional at Michigan State University. Both the appropriate dean and the instructor of the course in which a student charged with academic dishonesty is alleged to have committed a dishonest act must recommend the case of the student to the Student-Faculty Judiciary. Id. See note 172 supra and accompanying text. 
Individual faculty members may require more in-class compositions from their students, in order to have a substantial body of written work from each student against which to compare any submitted term paper. In some instances a more imaginative selection of topics for student papers will decrease greatly the likelihood that students will be able to locate copy papers which are on point. ${ }^{173}$ Additionally, some faculty members may wish to give greater weight to final examinations, thereby undoubtedly re-evaluating the need for and usefulness of term papers. It is not only unlawful but unnecessary to curtail first amendment freedoms in order to control a problem capable of being resolved by colleges and universities themselves.

172. But one commentator has used the term "term-paper junkie" to tefer to the student who made the following statement:

Once you start using these things you're more or less hooked. You can't

take C's and D's when you know you could buy A's and B's, and besides, if anyone found out what I really write like, then they'd know I didn't write the things they'd already given me good grades for. You know how sometimes im a textbook there's [sic] questions at the end of the chapters, and the teacher will tell you to write a few paragraphs on some of them for homework. I've even had to buy that. Rosenberg 215 .

173. A Yeshiva University professor ruefully acknowledged that "if we in the academic world did not misuse the idea of a paper, if we read and returned the paper, if we worked with the student while he wrote it, if we made the topics a bit more relevant, then these [term-paper] organizations would die out on their own account." Stavisky, supra note 163 , at 453.

Other commentators have similarly placed the blame for the proliferation of term paper companies on outdated teaching techniques. Einsiedler, supra note 19, at 46 (comments of William Banner, Associate Dean of the College cf Liberal Arts at Howard University); Letters, Crange, Winter 1972-73, at 4 ("the problem would not exist if faculty and administrators had really been close to students"). See also Otteu, "College Crisis," Wall Street Journal, Sept. 27, 1973, at 18, col. 3:

Honors courses and other special programs for particularly able students have fallen into disrepute as undemocratic. Grades have been dismissed as unfair to the less-prepared or as injecting alienating elements of competitiveness for the better prepared. Instead, there are more pass-fail courses, or courses where pseudo-scholarly papers substitute for tough exanıs. 